\title{
Characterization of Origin and Evolution of Formation Water in Buried Hill of Jizhong Depression, China, Using Multivariate Statistical Analysis of Geochemical Data
}

\author{
Fei Li ${ }^{1,2}$ and Jianhui Zeng ${ }^{1,2}$ \\ ${ }^{1}$ State Key Laboratory of Petroleum Resource and Prospecting, China University of Petroleum, Beijing, China \\ ${ }^{2}$ College of Geosciences, China University of Petroleum, Beijing, China \\ Correspondence should be addressed to Jianhui Zeng; zengjh@cup.edu.cn
}

Received 30 June 2017; Accepted 7 November 2017; Published 19 December 2017

Academic Editor: Jet-Chau Wen

Copyright (C) 2017 Fei Li and Jianhui Zeng. This is an open access article distributed under the Creative Commons Attribution License, which permits unrestricted use, distribution, and reproduction in any medium, provided the original work is properly cited.

\begin{abstract}
Groundwater samples from buried hill of Jizhong Depression were evaluated using two statistical analyses: hierarchical cluster analysis (HCA) and principal component analysis (PCA). The samples were classified into four clusters, $\mathrm{C1}$-C4, in $\mathrm{HCA}$ and the hydrochemical types of $\mathrm{C} 1-\mathrm{C} 4$ are $\mathrm{HCO}_{3}-\mathrm{Na}, \mathrm{Cl} \cdot \mathrm{HCO}_{3}-\mathrm{Na}, \mathrm{Cl}-\mathrm{Na}$, and $\mathrm{Cl}-\mathrm{Na} \cdot \mathrm{Ca}$. From $\mathrm{C} 1$ to $\mathrm{C} 2$, $\mathrm{C} 3$, and $\mathrm{C} 4$, the water-rock interaction becomes increasingly intensive, and $\mathrm{rNa} / \mathrm{rCl}$ gets lower while total dissolved solids and $\mathrm{r}(\mathrm{Cl}-\mathrm{Na}) / \mathrm{rMg}$ get higher. Three components of PCA explain $86.87 \%$ of the variance. Componentl (PC1), characterized by highly positive loadings in $\mathrm{Na}^{+}$and $\mathrm{Cl}^{-}$, is related to evaporation concentration. Component2 (PC2) is defined by highly positive loading in $\mathrm{HCO}_{3}{ }^{-}$and is related to influence of atmospheric water. With high positive loadings in $\mathrm{Ca}^{2+}$ and high negative loadings in $\mathrm{Na}^{+}$and $\mathrm{SO}_{4}{ }^{2-}$, component3 (PC3) suggests plagioclase albitization. The combination of HCA and PCA within the hydrogeological contexts allowed the division of study area into five dynamic areas. From recharge area to discharge area, the influence of atmospheric water gets weaker and water-rock interactions such as evaporation concentration and plagioclase albitization become intensive. Therefore groundwater in buried hill showed paths of hydrochemical evolution, from C1, to C2, C3, and C4. Buried hill reservoir in Jizhong Depression is mainly distributed in hydrodynamic blocking and discharge area; therefore the two regions can be the favorable areas for petroleum migration.
\end{abstract}

\section{Introduction}

In petroleum basins, hydrocarbon is always associated with formation water in porous stratigraphic units. Hydrocarbon generation, migration, accumulation, preservation, and loss all take place in the environment of formation water or are all accompanied by the participation of formation water (Davisson et al. 1991 [1-3]). Formation water in petroleum basins plays a vital role as media for the transport and redistribution of material and energy during the process of hydrocarbon generation, migration, and accumulation. The chemical composition, origin, and evolution can directly or indirectly reflect the closedness of sedimentary basin and hydrocarbon preservation conditions [4-6]. Therefore, understanding the origin, evolution, and controls on the composition of formation water is of considerable importance for successful appraisal of hydrocarbon exploration targets in sedimentary basins [7]. The chemical and isotopic compositions of formation water are widely applied in sedimentary basins to study the origins, evolution, and hydrogeological conditions. However, the origin and evolution of formation water are still being debated $[8,9]$. Generally speaking, origins of formation water have previously been attributed to meteoric water, evaporation concentrated seawater, or halite dissolution [1012].

In recent decades, multivariate statistical techniques such as hierarchical cluster analysis (HCA) and principal components analysis (PCA) have been successfully used as an effective tool to analyze the origin and evolution of shallow groundwater which is less than $200 \mathrm{~m}$ deep. Farnham et al. [13] applied principal components and clusters analysis to 
trace element chemistry of groundwater and identify rockwater interaction processes. In the study of Cloutier et al. [14], multivariate statistical methods were applied to classify the groundwater samples and to identify geochemical processes controlling groundwater geochemistry. Yidana et al. [15] applied cluster and factor analysis to assess the main controls on the chemistry of surface water resources. The above studies show that multivariate statistical techniques, such as HCA and PCA, significantly help to classify shallow groundwater and identify major mechanisms influencing groundwater chemistry.

As a second major tectonic unit of the Bohai Bay basin, the Jizhong Depression is a very typical area in China with enrichment of buried hill hydrocarbon reservoirs. The largest buried hill oilfield in China-Renqiu oilfield, covering an area of $80 \mathrm{~km}^{2}$, was discovered in Jizhong Depression in 1975 [16]. In the next ten years following its discovery, more than 20 buried hill oilfields were successively discovered. The proven oil reserves in these buried hill oilfields amount to $5.5 \times 10^{8} \mathrm{t}$, accounting for $60 \%$ of the total proven oil reserves in Jizhong Depression in that period $[17,18]$. However, the exploration of buried hill oil reservoirs entered a quiet stage in Jizhong Depression and few buried hill oil reservoirs were discovered in the following 20 years. In recent years, much progress has been made in the exploration technology of buried hill oil reservoirs and some buried hill oil reservoirs have been discovered, including Wengu 3, Niudong 1, Chang 3, and Chang 6, demonstrating good exploration prospect of buried hill oil reservoirs in Jizhong Depression [19-21].

Several studies have been performed to study the origin of formation water in buried hill [22-24], most of which used conventional graphical interpretative tools, such as piper plots, scatter plots, box plots, and stiff pattern diagram, to classify and account for the geochemical data. The understanding of the hydrogeochemistry of buried hill represents a good chance to further use statistical analysis, a quantitative method allowing us to classify formation water samples, to investigate correlations between the chemical parameters, and to appraise the similarity between the formation water samples. Compared to conventional graphical interpretative tools, the use of statistical methods for better identifying the processes controlling the geochemical evolution of formation water has some advantages. First of all, the utilisation of conventional graphical approach alone is always limited due to lack of objective criteria to discriminate different types of formation waters and the division into different hydrochemical facies is always qualitative rather than quantitative [25]. Secondly, conventional graphical methods are always short of clarity where large datasets are displayed [26].

The migration, accumulation, and preservation of oil reservoirs are also closely related to the movement of formation water and there is a good corresponding between petroleum accumulation and chemical composition. Li et al. [27] studied the chemical composition of Yanchang formation water in the Ordos Basin and revealed that the formation water with major ions of $\mathrm{Cl}^{-}$and $\mathrm{Na}^{+}$is more favorable for oil reservoir preservation. Wang et al. [28] investigated the implications of formation water features for hydrocarbon accumulation in Wenliu region in Dongpu sag, Bohai Bay Basin; the results showed that the areas with high concentration of $\mathrm{Cl}^{-}, \mathrm{Na}^{+}$, and $\mathrm{Ca}^{2+}$ correlate well to hydrocarbon enrichment areas. Therefore, understanding the chemical composition, origin, evolution, and controls on the composition of formation water will provide theoretical and practical guidance for exploration of buried hill oil reservoirs in Jizhong Depression. The depth of buried hill in Jizhong Depression is more than $2000 \mathrm{~m}$ and the deepest up to $5000 \mathrm{~m}$. In previous studies, multivariate statistical techniques such as HCA and PCA were mainly applied to analyze the origin and evolution of shallow groundwater. The shallow groundwater with lower temperature $\left(<50^{\circ} \mathrm{C}\right)$ is less than $200 \mathrm{~m}$ deep and human activities impact and atmospheric water play important part roles during the formation of shallow groundwater. Compared with shallow groundwater, the formation water in buried hill with high temperature $\left(>100^{\circ} \mathrm{C}\right)$ is more than $2000 \mathrm{~m}$ deep; the influences of human activities impact and atmospheric water get weak and waterrock interactions become intensive. Besides, some water-rock interactions can only occur in deep formation water with high temperature. Take plagioclase albitization effect, for example, it can only occur at the temperature ranging from $100^{\circ} \mathrm{C}$ to $150^{\circ} \mathrm{C}$ [29]. In this study, two multivariate methods, HCA and PCA, were used to analyze the geochemical data, and geological and hydrogeological conditions were employed to better assess the origin and evolution of deep formation water in buried hill of Jizhong Depression. Based on the distribution features of proved oil reserves in buried hill, the implication between evolution of formation water and hydrocarbon distribution, which will provide theoretical and practical guidance for exploration of similar oil reservoirs, has been investigated.

\section{Geology and Hydrogeology}

Jizhong Depression, located in the west of Bohai Gulf Basin (BGB) (Figure 1), is a Cenozoic sedimentary depression which formed on the basement of Huabei Platform. It is an elongated half-graben, bordered by the Yanshan uplift to the north, Xingheng uplift to the south, Taihangshan uplift to the west, and Cangxian uplift to the east, which covers an area of $32000 \mathrm{~km}^{2}$ (Figure 1). It is divided into three areas by two EW and SWW transformation belts, which are the east, middle, and west district, respectively. The Southern district included Shijiazhuang Sag, Jinxian Sag, Sulu Sag, and Jining uplift, the middle district consists of Raoyang Sag, Baoding Sag, Shenxian Sag, Gaoyang uplift, Shenze uplift, and Lixian Slope, and the north district can be divided into Beijing Sag, Daguang Sag, Langgu Sag, Xushui Sag, Wuqing Sag, Baxian Sag, Daxing uplift, Niutuozhen uplift, Rongcheng uplift, Niubei Slope, Yangcun Slope, and Wenan Slope.

In the extended geological period, Jizhong Depression experienced three developmental stages, namely, geosyncline, platform, and rifting stage. In the geosyncline developmental stage (3.5-1.8 billion years ago), the study area experienced the Fuping, Wutai, and Lvliang Orogenies, forming the ancient basement consisting of granite and hornblende schist. In the subsequent platform developmental stage (1.8-0.2 


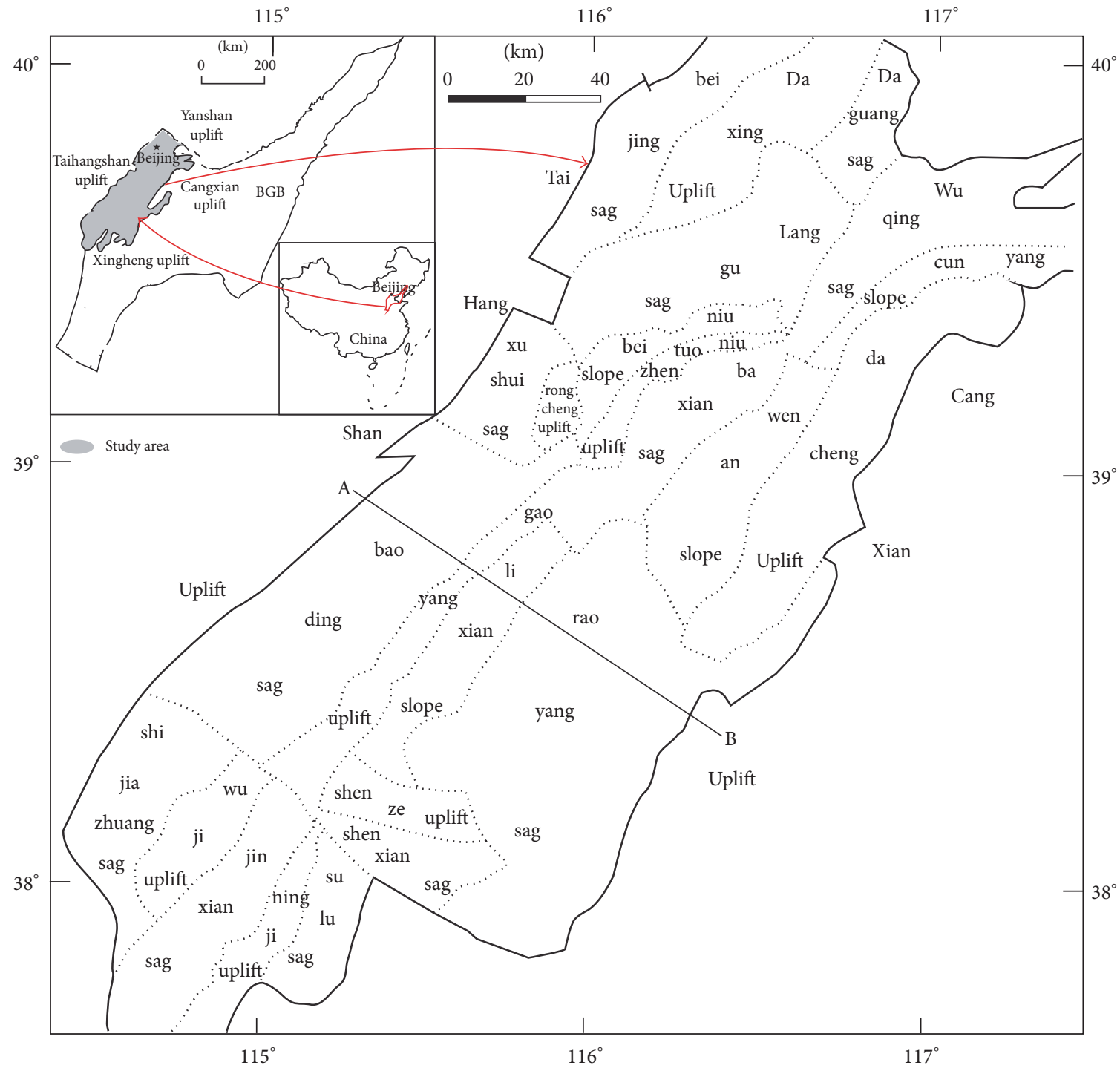

FIGURE 1: Sketch map showing location and structure of the Jizhong Depression.

billion years ago), the basin deposited a set of marine carbonate sediments with thicknesses of up to $6.8 \mathrm{~km}$. Under the influence of the Hercynian and Indosinian Orogenies, the marine carbonates repeatedly suffered weathering and denudation and the buried hills were formed in this stage. After the Indosinian orogenies, the study area moved into the stage of rifting basin ( 0.2 billion years ago up to the present), sedimenting a set of terrestrial deposits of up to $8000 \mathrm{~m}[30,31]$.

The basin fill of study area can be divided into two parts: the bottom part consists of Meso-Neoproterozoic through Paleozoic weathered marine carbonates, and the upper part is Cenozoic continental clastic sediment (Figures 2 and 3). From bottom to top, the upper part can be divided into six formations: the Kongdian (Ek), Shahejie (Es), Dongying (Ed), Guantao (Ng), Minghuazhen (Nm), and Pingyuan formations (Qp). The Pingyuan formations (Qp) includes yellow clay powder and fine sandstone. The Minghuazhen formation (Nm) consists of light grey sandstone, conglomeratic sandstones, and palm red mudstone. The Guantao formation $(\mathrm{Ng})$ consists of aubergine mudstone and light grey granular sandstone. The Dongying formation (Ed) is composed of three units: the lower part starts with amaranth mudstone and grey mudstone, the middle part is composed of grey mudstone interbedded with siltstone, and the upper part mainly consists of light grey sandstone and purple mudstone layer. The Shahejie formation (Es) can be further divided into four members based on lithology and electrical properties: Shahejie $1\left(E_{1}\right)$, Shahejie $2\left(E_{2}\right)$, Shahejie $3\left(E_{3}\right)$, and Shahejie $4\left(\mathrm{Es}_{4}\right)$. Shahejie 1 includes grey mudstone, calcareous shale, and calcareous sandstone, which gradually change upward into amaranth mudstone and grey sandstone. Shahejie 2 consists of red to purplish-red sandstone and mudstone. The Shahejie 3 is composed of dark grey mudstones interbedded with fine-grained sandstones, which is one of the most important source rocks. Shahejie $4\left(\mathrm{Es}_{4}\right)$ consists 


\begin{tabular}{|c|c|c|c|c|c|c|}
\hline \multicolumn{2}{|c|}{ Stratigraphic age } & Formation & Member & Stratum & Lithology & Sedimentary \\
\hline \multirow{9}{*}{ Cenozoic } & Quaternary & Pingyuan formation & & $\mathrm{Q} p$ & \begin{tabular}{lll|}
$\ddot{*}$ & $\ddot{\theta}$ &.
\end{tabular} & \multirow{5}{*}{$\begin{array}{c}\text { Fluvial } \\
\text { facies }\end{array}$} \\
\hline & \multirow{2}{*}{ Neogene } & $\begin{array}{l}\text { Minghuazhen } \\
\text { formation }\end{array}$ & & $\mathrm{N} m$ & \begin{tabular}{|l|}
$\ldots \ldots$ \\
--1 \\
\end{tabular} & \\
\hline & & Guantao formation & & $\mathrm{Ng}$ & $\ddot{\sim} \sim \ddot{\sim}$ & \\
\hline & \multirow{6}{*}{ Palaeogene } & $\begin{array}{l}\text { Dongying } \\
\text { formation }\end{array}$ & & $\mathrm{E} d$ & 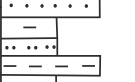 & \\
\hline & & \multirow{4}{*}{$\begin{array}{l}\text { Shahejie } \\
\text { formation }\end{array}$} & Number 1 & $\mathrm{E} s_{1}$ & \begin{tabular}{|l|l|}
- & \\
$-\cdot$ & \\
-- & \\
- & \\
-1
\end{tabular} & \\
\hline & & & Number 2 & $\mathrm{E} s_{2}$ & 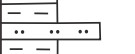 & \multirow{2}{*}{$\begin{array}{l}\text { Lacustrine } \\
\text { facies }\end{array}$} \\
\hline & & & Number 3 & $\mathrm{E} s_{3}$ & \begin{tabular}{|l|}
-1 \\
-- \\
-- \\
$-1-$. \\
\end{tabular} & \\
\hline & & & Number 4 & $\mathrm{E} s_{4}$ & $\begin{array}{|lll|}\cdot & \cdot & \cdot \\
- & - & \\
\cdot & \cdot & \\
- & - & \\
\cdot & \cdot & \\
- & - & \\
\end{array}$ & \multirow[t]{2}{*}{$\begin{array}{l}\text { Delta } \\
\text { facies }\end{array}$} \\
\hline & & $\begin{array}{l}\text { Kongdian } \\
\text { formation }\end{array}$ & & $\mathrm{E} k$ & 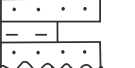 & \\
\hline \multirow[b]{2}{*}{ Paleozic } & Ordovician & & & $\mathrm{O}$ & 1 & \multirow{2}{*}{$\begin{array}{l}\text { Open } \\
\text { platform } \\
\text { facies }\end{array}$} \\
\hline & Cambrian & & & $\epsilon$ & & \\
\hline $\begin{array}{c}\text { Mesoprotero- } \\
\text { zoic }\end{array}$ & $\begin{array}{l}\text { Jixian } \\
\text { system }\end{array}$ & & & $J x w$ & 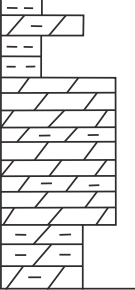 & $\begin{array}{l}\text { Restricted } \\
\text { platform } \\
\text { facies }\end{array}$ \\
\hline
\end{tabular}
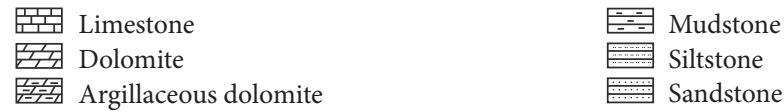

FIgURE 2: Stratigraphic histogram of the Jizhong Depression.

of grey mudstone and light grey sandstone interbedded with dolomite and gypsum, which is another important source rock. The Kongdian formation (Ek) includes variegated sandstone and red sandy mudstone, which gradually change upward into grey mudstone interbedded with gypsum mudstone [32].

The bottom part, weathered marine carbonate, consists of the Wumishan formation of the Jixian system (Jxw); Cambrian $(\epsilon)$ and Ordovician $(\mathrm{O})$ are the focus of this study. The Wumishan formation of the Jixian system, mainly distributed in the west of study area, is composed of dolomite and argillaceous dolomite. Cambrian $(\epsilon)$ and Ordovician, mainly distributed in the east of study area, consist of limestone. The buried hills, consisting of weathered marine carbonates, are directly covered by $\mathrm{Es}_{4}$-Ek or $\mathrm{Es}_{3}$ which are two primary hydrocarbon source rocks in study area. The hydrocarbon, generated from $\mathrm{Es}_{4}$-Ek or $\mathrm{Es}_{3}$ source rocks, migrated directly or through the fault-unconformity to the buried hill trap.

In the study area, there are five aquifers $\left(\mathrm{Ng}, \mathrm{Ed}, \mathrm{Es}_{2}\right.$ and $\mathrm{Ek}$, and buried hill) and four aquitards $\left(\mathrm{Nm}, \mathrm{Es}_{1}, \mathrm{Es}_{3}\right.$, and $\left.\mathrm{Es}_{4}\right)$. Formation water in the $\mathrm{Ng}$ formations consisting of fluvial facies is characterized by lower salinity $(<5 \mathrm{~g} / \mathrm{l})$ and high $\mathrm{rNa} / \mathrm{rCl}(>3.0)$ [33]. The stable isotope value of formation water in the $\mathrm{Ng}$ formation, which is similar to present rainwater, suggested that it is related to the influence of atmospheric water. The Ek, Es, and Ed formations, consisting of terrestrial facies lake basin depositions which are more than $2000 \mathrm{~m}$ deep, rarely outcrop. The formation water in $\mathrm{Ek}, \mathrm{Es}$, and Ed formations is characterized by higher salinity $(10 \sim 100 \mathrm{~g} / \mathrm{l})$ and lower $\mathrm{rNa} / \mathrm{rCl}(<3.0)$ [33]. In the study of $\mathrm{Qu}$ et al. [24], the application of isotopic composition is used to trace the origin of formation water in Ek, Es, and Ed, which is mainly from sedimentary water and small amount of atmospheric water. Evaporation concentration effect plays an important part role during the evolution of formation water in the Ek, Es, and Ed. Du et al. [33] studied the fluid potential of Ek, Es, and Ed and the migration direction of the formation water is from the depression center to the edge. The weathered marine carbonates widely outcrop in the west of Taihang Mountains; the main flow path of formation water in 


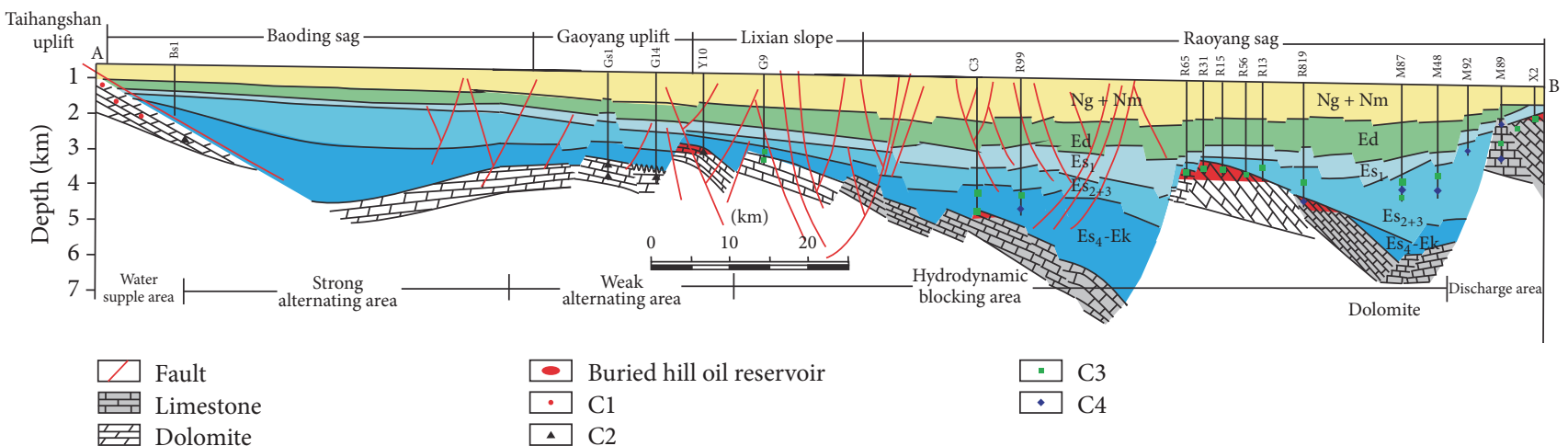

Figure 3: Schematic map of the cross-section A-B. See Figure 1.
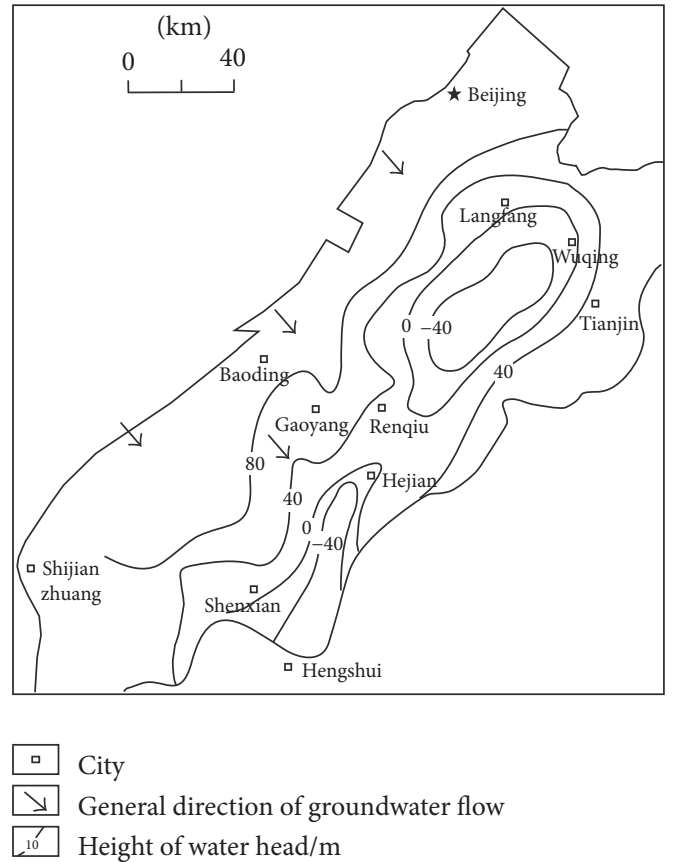

FIGURE 4: The water head of formation water in buried hill, Jizhong Depression.

buried hill is generally from west to east (Figure 4). Before the deposition of Ek formation, the formation water in buried hill is mainly from ancient meteoric water. During the deposition of Ek, Es, and Ed formations, the formation water from tertiary mudstone is expelled into the buried hill. Nowadays, the buried hill formation water at the edge of depression is mainly from meteoric water. Therefore, the formation water in buried hill is characterized of medium salinity $(5 \sim 50 \mathrm{~g} / \mathrm{l})$ [33].

\section{Methodology}

As mentioned, each sampling site is characterized by a large number of chemical and physical variables, making the regional hydrogeochemical study a multivariate problem. In this study, 6 chemical variables $\left(\mathrm{Ca}^{2+}, \mathrm{Mg}^{2+}, \mathrm{Na}^{+}, \mathrm{HCO}_{3}{ }^{-}\right.$,
$\mathrm{Cl}^{-}$, and $\mathrm{SO}_{4}{ }^{2-}$ ), in 459 samples were analyzed using hierarchical cluster analysis (HCA) and principal components analysis (PCA). The HCA and PCA were used as a quantitative and independent approach for groundwater classification allowing grouping of the groundwater samples and making of correlations between chemical parameters and groundwater samples, respectively.

3.1. Hierarchical Cluster Analysis (HCA). The hierarchical cluster analysis is a data classification method, which are widely applied in the classification of hydrogeochemical data $[34,35]$. In this study, the square of the Euclidean distance (E) was used in HCA as the measure of similarity performed over all variables included in $\mathrm{HCA}\left(\mathrm{Ca}^{2+}, \mathrm{Mg}^{2+}, \mathrm{Na}^{+}, \mathrm{HCO}_{3}{ }^{-}\right.$, $\mathrm{Cl}^{-}$, and $\mathrm{SO}_{4}{ }^{2-}$ ). HCA using Ward's algorithm was conducted on the remaining complete samples where all input variables were measured. Compared to other methods, Ward's method is much more effective in forming clusters because it uses an analysis of variance approach to evaluate the distances between clusters [35-37].

During the clustering procedure, HCA first considers each observation separately and then combines the two observations that are closest together to form a new group. After recomputing the distance between the groups, the two groups then closest together are combined, and this process is repeated until only one group remains. Resulting from this procedure is a dendrogram (e.g., [14]). To avoid misclassifications arising from the effect of parameters with the highest variances on the calculation of Euclidean distance [14], the variance for each variable is standardized to their corresponding $Z$ scores, which are calculated by the following equation [38]:

$$
Z_{i}=\frac{(X i-\text { mean })}{s},
$$

where $Z_{i}$ is the standardized $Z$ scores, $s$ is the standard deviation of the distribution, mean is the mean value of the normal distribution from each datum, and $X i$ is the value of each variable.

3.2. Principal Component Analysis (PCA). The PCA is a data transformation method that attempts to reduce the 
TABLE 1: The geochemical characteristics of different types of formation water in buried hill, Jizhong Depression.

\begin{tabular}{|c|c|c|c|c|c|c|c|}
\hline \multirow{2}{*}{ Type } & \multirow{2}{*}{$\begin{array}{c}\text { Total } \\
\text { dissolved } \\
\text { solid }(\mathrm{g} / \mathrm{l})\end{array}$} & \multicolumn{2}{|c|}{ Hydrochemical type } & \multirow{2}{*}{$\begin{array}{l}\text { Main cation and } \\
\text { anion } \\
\text { (percentage of } \\
\text { meq) }\end{array}$} & \multicolumn{2}{|c|}{$\begin{array}{l}\text { Ionic ratio (Min } \sim \operatorname{Max}) \\
\text { average }\end{array}$} & \multirow{2}{*}{$\begin{array}{l}\text { Occurrence } \\
\text { location }\end{array}$} \\
\hline & & $\begin{array}{c}\text { Surin } \\
\text { classification }\end{array}$ & $\begin{array}{c}\text { Shu kraft } \\
\text { classification }\end{array}$ & & $\mathrm{rNa} / \mathrm{rCl}$ & $\begin{array}{c}\mathrm{r}(\mathrm{Cl}- \\
\mathrm{Na}) / \mathrm{rMg}\end{array}$ & \\
\hline $\mathrm{C} 1$ & $<1$ & $\mathrm{NaHCO}_{3}$ & $\begin{array}{c}\mathrm{HCO}_{3}-\mathrm{Na} \\
\text { and } \mathrm{HCO}_{3}^{-} \\
\mathrm{Na} \cdot \mathrm{Mg} \cdot \mathrm{Ca}\end{array}$ & $\begin{array}{c}\mathrm{HCO}_{3}^{-}(64 \%) \\
\mathrm{Na}^{+}(77 \%)\end{array}$ & $\begin{array}{c}(3.0 \sim 5.0) \\
3.9\end{array}$ & $\begin{array}{c}(-70 \sim-50) \\
-61\end{array}$ & $\begin{array}{c}\text { In west of } \\
\text { Taihangshan } \\
\text { uplift }\end{array}$ \\
\hline $\mathrm{C} 2$ & $1 \sim 10$ & $\mathrm{NaHCO}_{3}$ & $\mathrm{Cl} \cdot \mathrm{HCO}_{3}-\mathrm{Na}$ & $\begin{array}{c}\mathrm{Cl}^{-}(55 \%) \\
\mathrm{HCO}_{3}^{-}(39 \%) \\
\mathrm{Na}^{+}(94 \%)\end{array}$ & $\begin{array}{c}(1.1 \sim 2.8) \\
1.9\end{array}$ & $\begin{array}{c}(-55 \sim 10) \\
-33\end{array}$ & $\begin{array}{l}\text { In high uplift } \\
\text { of buried hill }\end{array}$ \\
\hline C3 & $5 \sim 30$ & $\begin{array}{c}\mathrm{NaHCO}_{3} \text { and } \\
\mathrm{CaCl}_{2}\end{array}$ & $\mathrm{Cl}-\mathrm{Na}$ & $\begin{array}{c}\mathrm{Cl}^{-}(95 \%) \\
\mathrm{Na}^{+}(82 \%)\end{array}$ & $\begin{array}{c}(0.85 \sim 1.4) \\
1.1\end{array}$ & $\begin{array}{c}(-12 \sim 9) \\
-3\end{array}$ & $\begin{array}{l}\text { The slope } \\
\text { between the } \\
\text { buried hill } \\
\text { and sag }\end{array}$ \\
\hline $\mathrm{C} 4$ & $8 \sim 50$ & $\mathrm{CaCl}_{2}$ & $\mathrm{Cl}-\mathrm{Na} \cdot \mathrm{Ca}$ & $\begin{array}{l}\mathrm{Cl}^{-}(93 \%) \\
\mathrm{Na}^{+}(62 \%) \\
\mathrm{Ca}^{2+}(33 \%)\end{array}$ & $\begin{array}{c}(0.3 \sim 1.0) \\
0.7\end{array}$ & $\begin{array}{c}(4 \sim 18) \\
8\end{array}$ & $\begin{array}{c}\text { In buried hill } \\
\text { of sag }\end{array}$ \\
\hline
\end{tabular}

complexity of large multivariate datasets and reveal a simple underlying structure that is assumed to exist in the dataset [14, 39-41]. This technique, which is related to correlations between variables in the dataset, is referred to by Davis [38] as the R-mode. The number of components was based on the Kaiser criterion, for which only the components having eigenvalues greater than 1 are kept [42]. The principal component is expressed by the following linear equation:

$$
z_{i j}=a_{i 1} \cdot x_{1 j}+a_{i 2} \cdot x_{2 j}+a_{i 3} \cdot x_{3 j}+\cdots+a_{i m} \cdot x_{m j},
$$

where $a$ is component loading, $z$ the component score, $x$ the measure value, $i$ the component number, $j$ the sample number, and $m$ the total number of variables. The advantage of PCA is that it integrates message on all hydrogeochemical dates from the given sample into a single number allowing the simultaneous analysis of those parameters that control the variability of the data. Combined with spatial visualisation, PCA is a helpful method to identify the processes that control formation water evolution and the conceptual model of regional formation water flow.

\section{Results}

4.1. Hierarchical Cluster Analysis (HCA). The dendrogram shows the result of hierarchical cluster analysis of the 459 buried hill formation water samples (Figure 5). In the project, the Euclidean distance (E) is used as the measure of similarity between different formation water samples. The samples with large similarity are first classified. Then, groups of samples are joined with a linkage rule, and the steps are repeated until all samples have been grouped $[14,25,43]$. In the study, the phenon line was drawn across the dendrogram at a linkage distance of about 30 (Figure 5). Therefore, formation water samples with a linkage distance less than 30 are classified into the same group. The location of the phenon line divided the dendrogram into four clusters of buried hill formation water samples which are C1, C2, C3, and C4 (Figure 5). Large differences in geochemical characteristics among $\mathrm{C} 1-\mathrm{C} 4$ can be seen in Table 1 and Figures 6 and 7.

Samples from $\mathrm{Cl}$ with the lowest total dissolved solids $(<1 \mathrm{~g} / \mathrm{l})$ primarily occur in the west of Taihangshan uplift, the main anion is $\mathrm{HCO}_{3}{ }^{-}$and the main cation is $\mathrm{Na}^{+}$, hydrochemical type of Shu kraft classification is mainly $\mathrm{HCO}_{3}-\mathrm{Na}$, and a small number is $\mathrm{HCO}_{3}-\mathrm{Na} \cdot \mathrm{Mg} \cdot \mathrm{Ca}$. The type of Surin classification is $\mathrm{NaHCO}_{3}$. The ionic ratio ranges between 3.0 and 5.0 for $\mathrm{rNa} / \mathrm{rCl}$ and between -70 and -50 for $\mathrm{r}(\mathrm{Cl}-\mathrm{Na}) / \mathrm{rMg}$. Based on the above dates, the $\mathrm{C} 1$ water is in open hydrogeochemical environment.

C2 with lower total dissolved solids $(1-10 \mathrm{~g} / \mathrm{l})$ is mainly in high uplift of buried hill, the main anions are $\mathrm{Cl}^{-}$and $\mathrm{HCO}_{3}{ }^{-}$and the main cation is $\mathrm{Na}^{+}$, and hydrochemical type of Shu kraft classification is $\mathrm{Cl} \cdot \mathrm{HCO}_{3}-\mathrm{Na}$. The type of Surin classification is also $\mathrm{NaHCO}_{3} \cdot \mathrm{rNa} / \mathrm{rCl}$ values mainly vary between 1.1 and 2.8 , and $\mathrm{r}(\mathrm{Cl}-\mathrm{Na}) / \mathrm{rMg}$ values vary between -55 and -10 . Based on the above dates, the $\mathrm{C} 2$ water is in semiopen hydrogeochemical environment.

C3 with higher total dissolved solids $(5-30 \mathrm{~g} / \mathrm{l})$ is mainly in the slope between the buried hill and sag, the main anion is $\mathrm{Cl}^{-}$and the main cation is $\mathrm{Na}^{+}$, and hydrochemical type of Shu kraft classification is Cl-Na. The type of Surin classification is $\mathrm{NaHCO}_{3}$ and $\mathrm{CaCl}_{2} \cdot \mathrm{rNa} / \mathrm{rCl}$ values mainly vary between 0.85 and 1.4 , and $\mathrm{r}(\mathrm{Cl}-\mathrm{Na}) / \mathrm{rMg}$ values vary between -12 and 9. Based on the above dates, the C3 water is in semiclosed hydrogeochemical environment.

C4 with the highest total dissolved solids $(8-50 \mathrm{~g} / \mathrm{l})$ is mainly in buried hill of sag, the main anion is $\mathrm{Cl}^{-}$and the main cations are $\mathrm{Na}^{+}$and $\mathrm{Ca}^{2+}$, and hydrochemical type of Shu kraft classification is $\mathrm{Cl}-\mathrm{Na} \cdot \mathrm{Ca}$. The type of Surin classification is $\mathrm{CaCl}_{2}$. The $\mathrm{rNa} / \mathrm{rCl}$ and $\mathrm{r}(\mathrm{Cl}-\mathrm{Na}) / \mathrm{rMg}$ of $\mathrm{C} 4$ display relatively narrow range from 0.3 to 1.0 and from 4 to 18 , respectively. Based on the above dates, the $\mathrm{C} 4$ water is in closed hydrogeochemical environment.

With the burial depth increment, the type of formation water changed from $\mathrm{C} 1$ to $\mathrm{C} 2, \mathrm{C} 3$, and then $\mathrm{C} 4$. The waterrock interaction becomes increasingly intensive and the total 


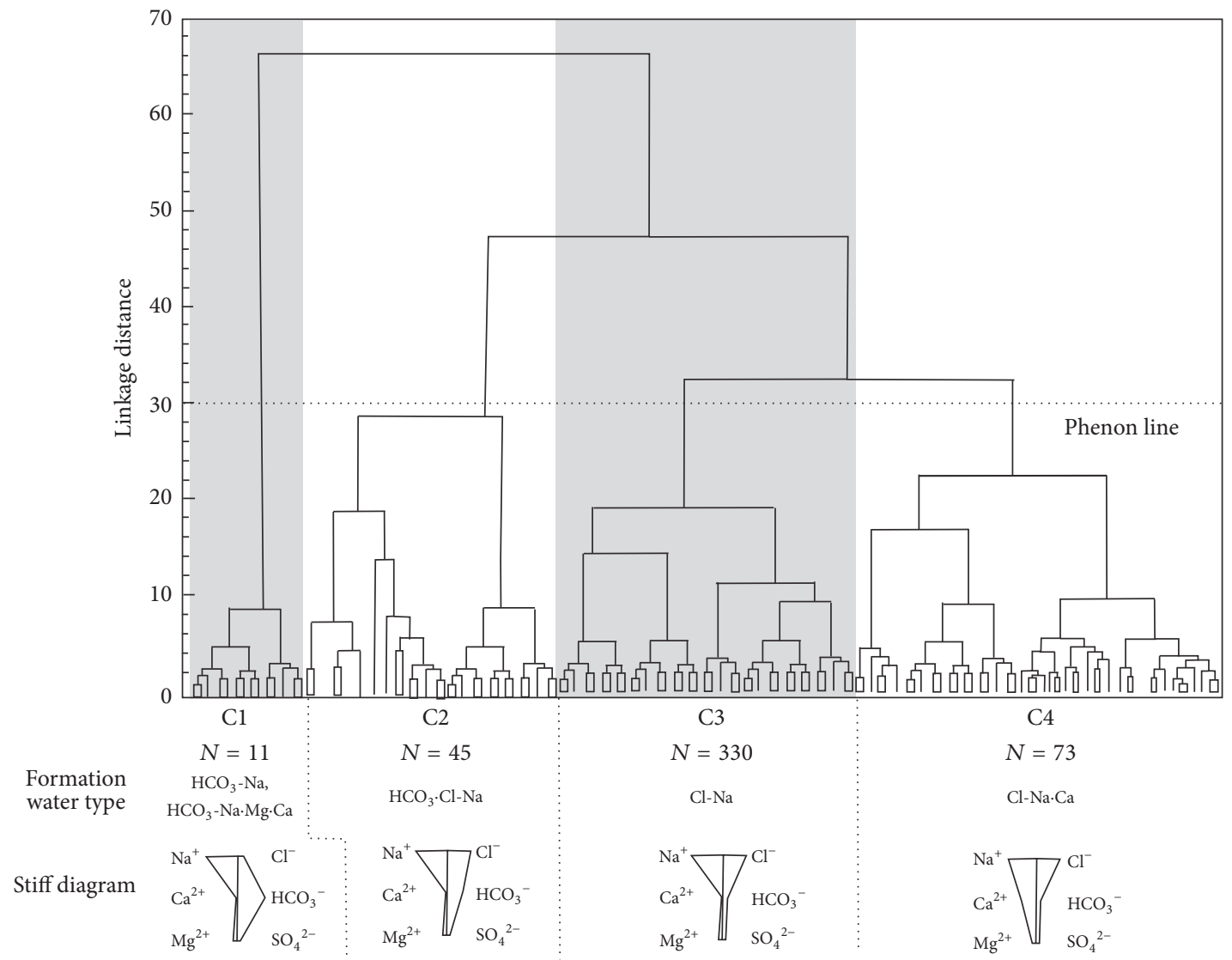

Figure 5: Dendrogram for the formation water samples in buried hill of Jizhong Depression, showing the division into four clusters and the median concentration Stiff diagram of each cluster.

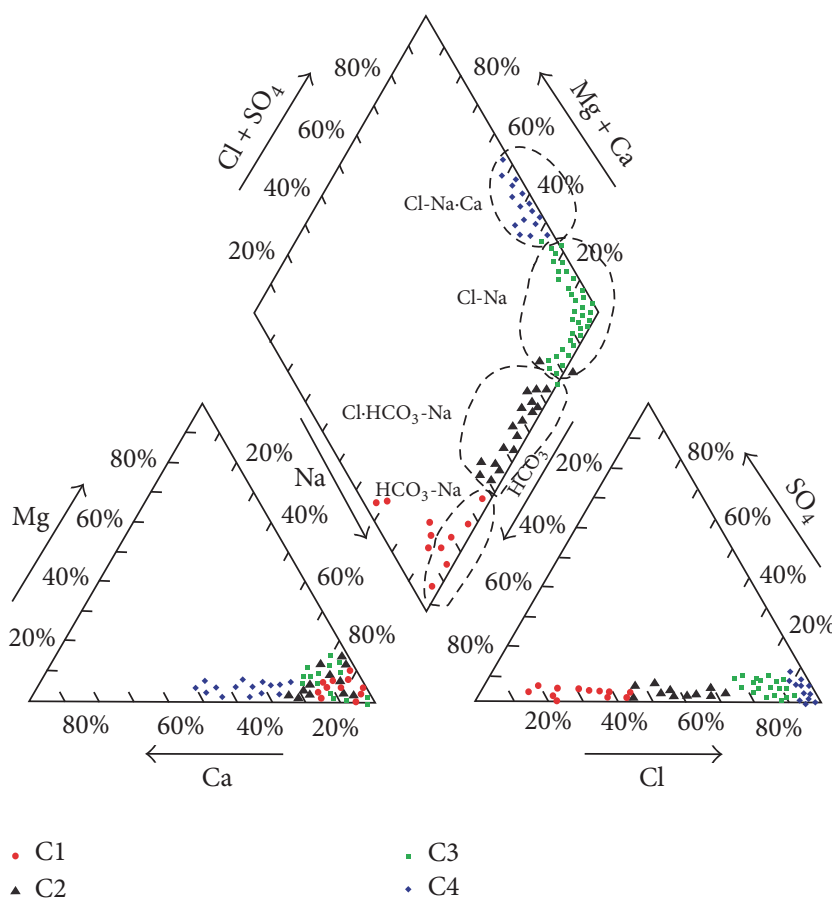

FIGURE 6: Piper diagram of formation water samples from buried hill of Jizhong Depression. dissolved solid gets higher, resulting in a transition of the water chemical type; for example, $\mathrm{rNa} / \mathrm{rCl}$ and the $\mathrm{rSO}_{4} \times$ $100 / \mathrm{rCl}$ get lower while $\mathrm{r}(\mathrm{Cl}-\mathrm{Na}) / \mathrm{rMg}$ gets higher.

In this study, the types of formation water in $\mathrm{Es}_{3}$ and $\mathrm{Es}_{4}+$ Ek had also been studied (Figure 3). From Figure 3, samples from $\mathrm{Es}_{3}$ and $\mathrm{Es}_{4}+\mathrm{Ek}$ have $\mathrm{Cl}-\mathrm{Na}(\mathrm{C} 3)$ and $\mathrm{Cl}-$ $\mathrm{Na} \cdot \mathrm{Ca}(\mathrm{C} 4)$ formation water. Therefore, $\mathrm{Es}_{3}$ and $\mathrm{Es}_{4}+\mathrm{Ek}$, dominated by samples of $\mathrm{C} 3$ and $\mathrm{C} 4$, are in semiclosed-closed hydrogeochemical environment.

4.2. Principal Components Analysis (PCA). Three principal components were extracted from the standardized geochemical dataset of buried hill formation water, which suggests only the three principal components with eigenvalues greater than 1 (Table 2). The three components identified in this study cumulatively can account for $86.870 \%$ of the total variance in the original dataset. Table 2 presents the principal component loadings for the three components, as well as their respective explained variance. Component1 (PC1) accounts for the greatest amount of the variance (approximately $53.777 \%$ ) and shows a strong positive loadings in $\mathrm{Na}^{+}$and $\mathrm{Cl}^{-}$which are 0.878 and 0.953 , respectively (Figure 8 and Table 2). Component2 (PC2) explains $19.042 \%$ of the variance and is characterized by highly positive loadings in $\mathrm{HCO}_{3}{ }^{-}$which is 0.799 (Figure 8 and Table 2). Component3 (PC3) explains 
TABLE 2: Table of component weightings, principal component eigenvalues, and variance of principal components.

\begin{tabular}{lccc}
\hline Parameters & PC1 & PC2 & PC3 \\
\hline $\mathrm{Na}^{+}$ & $\mathbf{0 . 8 7 8}$ & 0.256 & $-\mathbf{0 . 6 8 2}$ \\
$\mathrm{Mg}^{2+}$ & 0.281 & -0.137 & 0.280 \\
$\mathrm{Ca}^{2+}$ & 0.219 & -0.219 & $\mathbf{0 . 7 5 6}$ \\
$\mathrm{HCO}_{3}{ }^{-}$ & 0.288 & $\mathbf{0 . 7 9 9}$ & 0.324 \\
$\mathrm{Cl}^{-}$ & $\mathbf{0 . 9 5 3}$ & 0.093 & 0.249 \\
$\mathrm{SO}_{4}{ }^{2-}$ & 0.571 & 0.021 & $-\mathbf{0 . 5 7 0}$ \\
Eigenvalue variance & 3.227 & 1.343 & 1.043 \\
Explained variance (\%) & 53.777 & 19.042 & 14.051 \\
Cumulative \% of variance & 53.777 & 72.820 & 86.870 \\
\hline
\end{tabular}
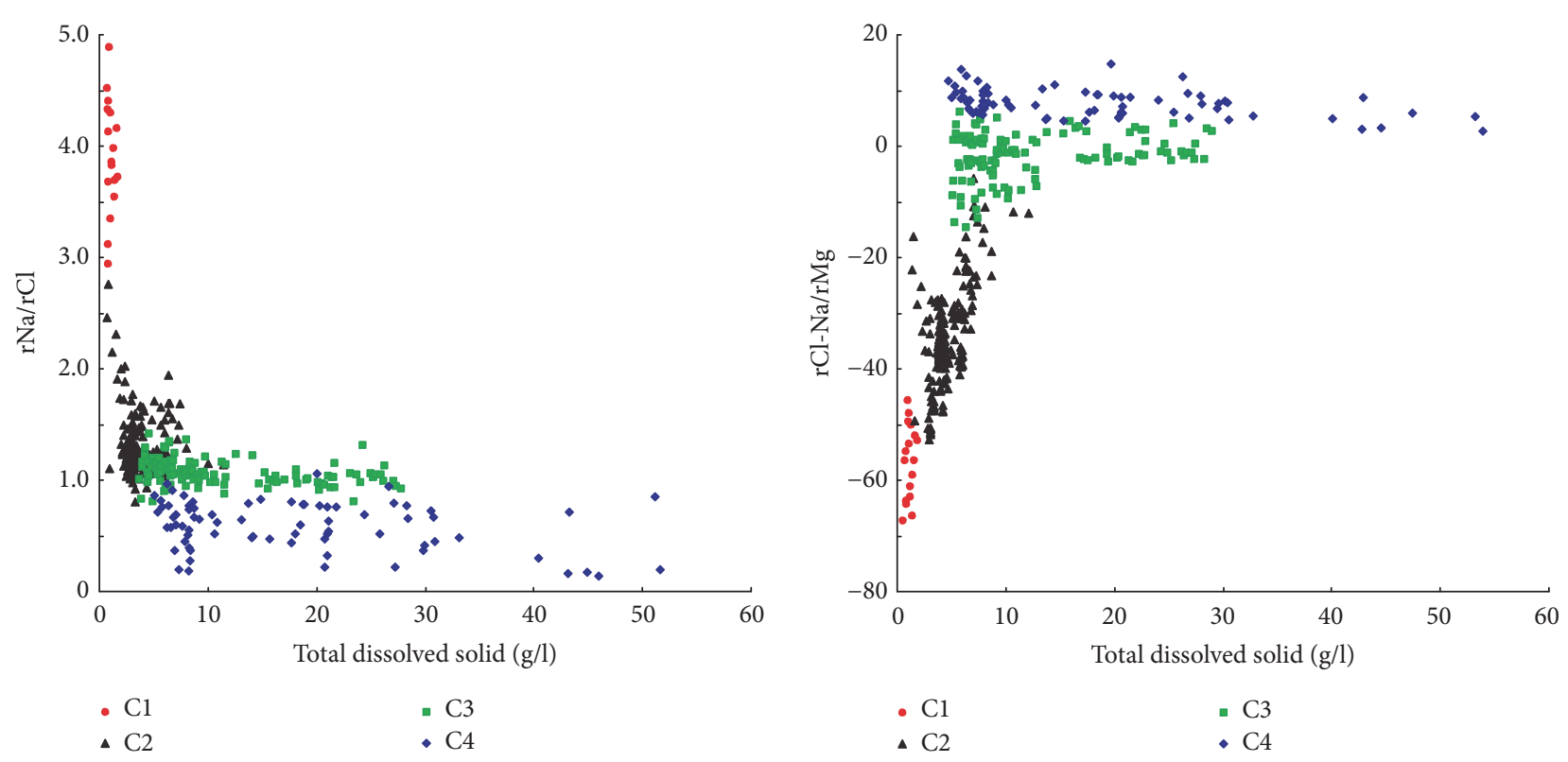

FIGURE 7: The relationship between salinity and sodium chloride coefficient and metamorphic coefficient from different types of formation water in buried hill of Jizhong Depression.

about $14.051 \%$ of the variance and shows a strong negative loading of $\mathrm{SO}_{4}{ }^{2-}$ and $\mathrm{Na}^{+}$and strong positive loadings of $\mathrm{Ca}^{2+}$ which are $-0.570,-0.682$, and 0.756 , respectively (Figure 8 and Table 2). Figure 9 shows a scatter plot of the projected scores of PC1-PC2 and PC1-PC3 for the above four types of formation water. From Figure 9, C1 is mainly affected by $\mathrm{PC} 2, \mathrm{C} 2$ is mainly affected by PC1 and PC2, C3 is mainly affected by PC1, and C4 is mainly affected by PC1 and PC3.

\section{Discussion}

5.1. Origin of Formation Water in Buried Hill. Formation water in sedimentary basin is usually derived from leached water, sedimentation water, endogenous water, or the mixture of them $[44,45]$. The leached water is mainly meteoric water enriched in $\mathrm{CO}_{2}$ and $\mathrm{O}_{2}$, sedimentation water is the ancient groundwater which evolved from the ancient surface water, and endogenous water is the high heat fluid from deep earth [46]. The origin of formation water and a series of physical and chemical reaction, such as halite dissolution, evaporation concentrated seawater, generation of organic matter, and biodegradation, will affect the hydrochemical characteristic of formation water. The multivariate statistical methods of HCA and PCA do not indicate cause-and-effect relationships; they can only provide information from which such relationships can be inferred. Therefore, in order to better identify the physical and chemical processes controlling the geochemical evolution of groundwater, the results of the multivariate statistical analysis have to be combined with the knowledge of the geological and hydrogeological setting $[47,48]$.

5.1.1. C1 Type of Water. Samples from $\mathrm{Cl}$ have $\mathrm{HCO}_{3}-\mathrm{Na}$ and $\mathrm{HCO}_{3}-\mathrm{Na} \cdot \mathrm{Mg} \cdot \mathrm{Ca}$ formation water type and are characterized by the lowest total dissolved solids and $\mathrm{r}(\mathrm{Cl}-\mathrm{Na}) / \mathrm{rMg}$, highest $\mathrm{rNa} / \mathrm{rCl}$ of all clusters, suggesting that $\mathrm{Cl}$ is in open hydrogeochemical environment. According to the above study, $\mathrm{C} 1$ is mainly affected by PC2 which shows a strong positive loadings in $\mathrm{HCO}_{3}{ }^{-}$. Generally speaking, there are main three sources of $\mathrm{HCO}_{3}{ }^{-}$which are atmospheric water, dissolution of carbonate rocks, and weathering dissolution 

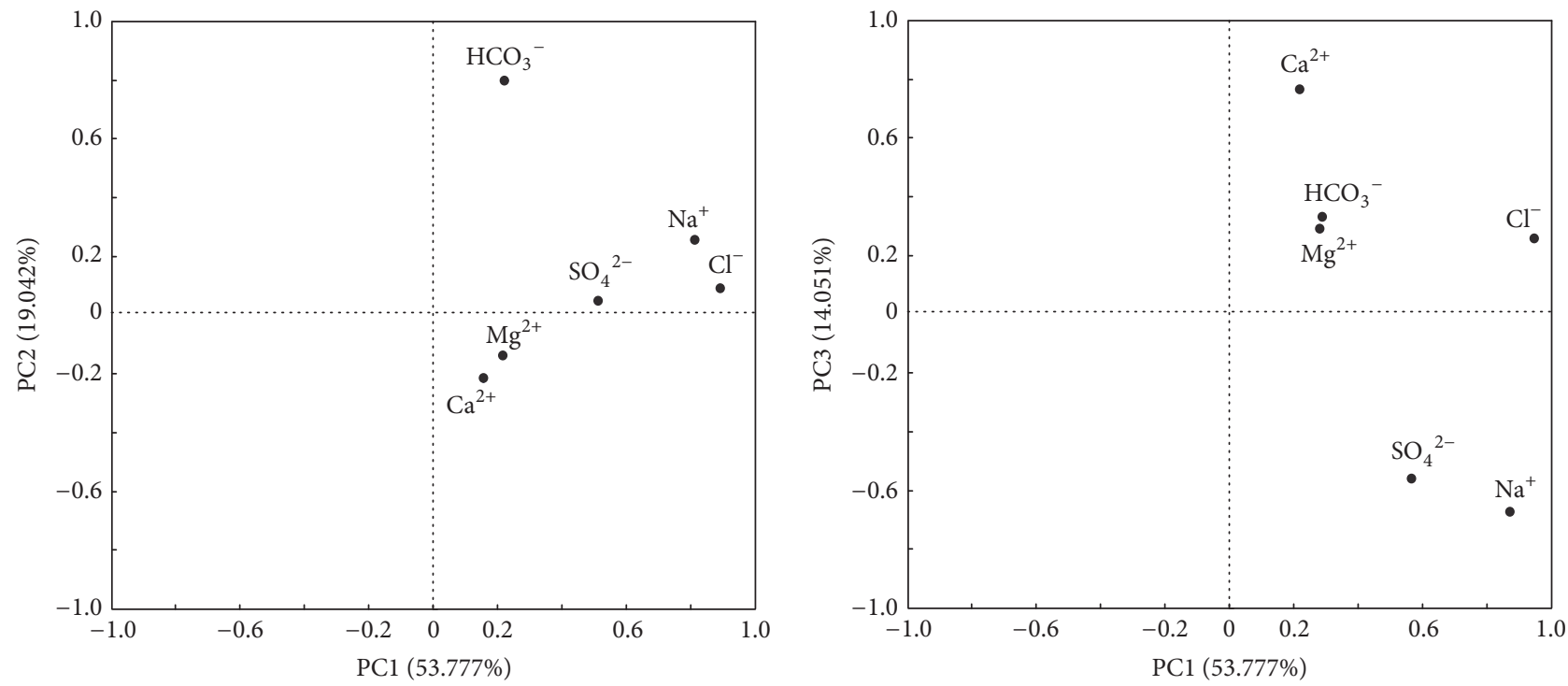

FIGURE 8: Plot of loadings for the three components with Varimax normalized rotation.
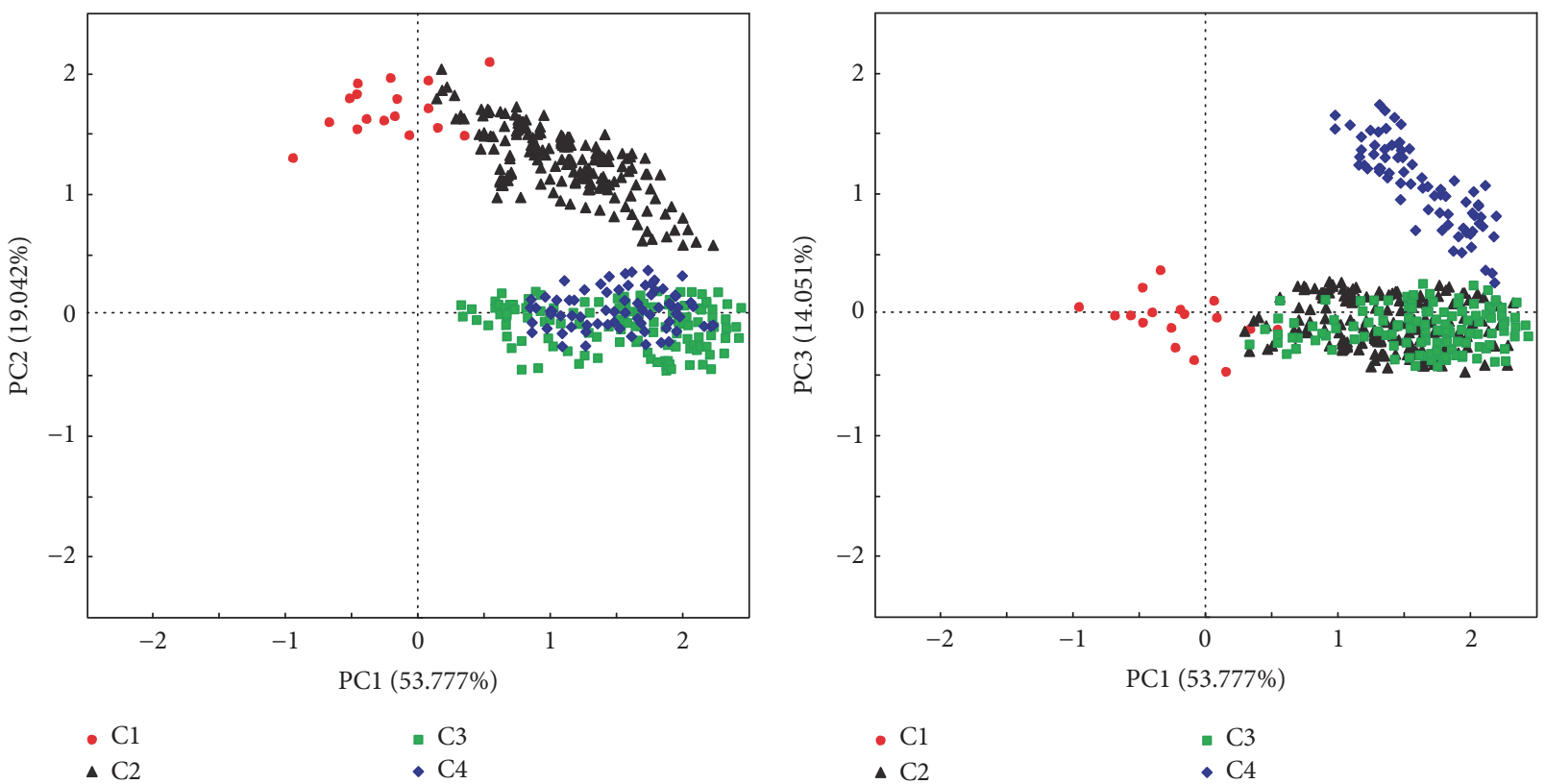

FIGURE 9: Plot of principal component scores for the first three components for the water samples labeled with the groundwater clusters.

of aluminosilicate minerals in magmatic and metamorphic rock areas. The lithology of the buried hill in the study area is mainly marine carbonates rocks, so the explanation that sources of $\mathrm{HCO}_{3}{ }^{-}$are from weathering dissolution of aluminosilicate minerals can also be eliminated. $\mathrm{Cl}$ with the lowest total dissolved solids $(<1 \mathrm{~g} / \mathrm{l})$ primarily occurs in the west of Taihangshan uplift where the weathered marine carbonates widely outcrop. So $\mathrm{Cl}$ may be from the dissolution of dolomite. The stable isotope values of $\mathrm{Cl}$ range between $-80.49 \%$ and $-71.53 \%$ o for $\delta \mathrm{D}$ and between $-11.37 \%$ and $-9.17 \%$ for $\delta^{18} \mathrm{O}$, respectively, which are similar to stable isotope values of the present rainwater $(\delta \mathrm{D}=-72.48 \%$ $-80.22 \%$ o, $\delta^{18} \mathrm{O}=-10.31 \%$ $\sim-11.28 \%$ ) [33]. In a word,
PC2 is related to the influences of atmospheric water and $\mathrm{C} 1$ is mainly derived from atmospheric water, partly affected by the dissolution of dolomite.

5.1.2. C2 Type of Water. Samples from C2 have $\mathrm{Cl} \cdot \mathrm{HCO}_{3}$ $\mathrm{Na}$ formation water and are characterized by the lower total dissolved solids and $\mathrm{r}(\mathrm{Cl}-\mathrm{Na}) / \mathrm{rMg}$, higher $\mathrm{rNa} / \mathrm{rCl}$ of all clusters, suggesting that $\mathrm{C} 2$ is in semiopen hydrogeochemical environment. The main differences between $\mathrm{C} 1$ and $\mathrm{C} 2$ are that $\mathrm{C} 2$ has higher $\mathrm{Na}^{+}$and $\mathrm{Cl}^{-}$concentration and lower $\mathrm{HCO}_{3}{ }^{-}$concentration than $\mathrm{C} 1$. $\mathrm{C} 2$ is mainly affected by PC1 and PC2. PC1 is defined by highly positive loading in $\mathrm{Na}^{+}$and $\mathrm{Cl}^{-}$, which are 0.878 and 0.953 , respectively. 
Geochemical processes of CP1 could be related to halite dissolution, evaporation concentrated seawater, or groundwater mixing with sea water. Davisson and Criss [49] used a mathematical transformation of $\mathrm{Na}, \mathrm{Ca}$, and $\mathrm{Cl}$ data an excess-deficit comparison of $\mathrm{Na}$ and $\mathrm{Ca}$ relative to seawater reference ratio, to explain the major ionic concentrations in numerous basinal fluids around the world. The mathematical transformations are

$$
\begin{aligned}
& \mathrm{Ca}_{\text {excess }}=\left[\mathrm{Ca}_{\text {meas }}-\left(\frac{\mathrm{Ca}}{\mathrm{Cl}}\right)_{\text {sw }} \times \mathrm{Cl}_{\text {meas }}\right] \times \frac{2}{40.08} \\
& \mathrm{Na}_{\text {deficit }}=\frac{\left[(\mathrm{Na} / \mathrm{Cl})_{\text {sw }} \times \mathrm{Cl}_{\text {meas }}-\mathrm{Na}_{\text {meas }}\right]}{22.99},
\end{aligned}
$$

where "sw" and "meas" refer to seawater concentrations and measured concentrations, respectively.

Figure 10 shows $\mathrm{Ca}_{\text {excess }}-\mathrm{Na}_{\text {deficit }}$ of formation water in buried hill. Samples from C2 show slight deficit in $\mathrm{Na}^{+}$and no deficit and excess in $\mathrm{Ca}^{2+}$, which are parallel to the sea evaporation line, suggesting that evaporation concentration effect plays an important role during the formation of $\mathrm{C} 2$. Therefore, $\mathrm{PCl}$ is related to the evaporation concentration effect and C2 is mainly derived from atmospheric water and evaporation concentration effect.

5.1.3. C3 Type of Water. Samples from C3 have Cl-Na formation water and are characterized by the higher total dissolved solids and $\mathrm{r}(\mathrm{Cl}-\mathrm{Na}) / \mathrm{rMg}$, lower $\mathrm{rNa} / \mathrm{rCl}$ of all clusters, suggesting that $\mathrm{C} 3$ is in semiclosed-closed hydrogeochemical environment. $\mathrm{C} 3$ is mainly affected by $\mathrm{PCl}$, suggesting that evaporation concentration effect plays an important part role during the formation of $\mathrm{C} 3$. This conclusion is also supported by Figure 10. Samples from C3 show much more deficit in $\mathrm{Na}^{+}$ and no deficit and excess in $\mathrm{Ca}^{2+}$, which are also parallel to the sea evaporation line (Figure 10).

5.1.4. C4 Type of Water. Samples from C4 have Cl-Na.Ca groundwater and are characterized by the highest total dissolved solids and $\mathrm{r}(\mathrm{Cl}-\mathrm{Na}) / \mathrm{rMg}$, lowest $\mathrm{rNa} / \mathrm{rCl}$ of all clusters, suggesting that $\mathrm{C} 4$ is in closed hydrogeochemical environment. C4 is mainly affected by $\mathrm{PC} 1$ and PC3, and PC3 is defined by highly positive loading in $\mathrm{Ca}^{2+}$ and highly negative scores in $\mathrm{Na}^{+}$, which are 0.878 and 0.953 , respectively. This association of chemical parameters is related to $\mathrm{Ca}^{2+}$ $\mathrm{Na}^{+}$ion exchange. Samples from C4 show deficit in $\mathrm{Na}^{+}$and excess in $\mathrm{Ca}^{2+}$, which are parallel to the Basinal Fluid Line (BFL), suggesting that plagioclase albitization effect plays an important part role during the formation of C4 (Figure 10). In a word, PC3 is related to the plagioclase albitization effect and $\mathrm{C} 4$ is mainly derived from evaporation concentration effect and plagioclase albitization effect.

5.2. Evolution of Formation Water in Buried Hill. According to the hydrodynamic conditions (relative hydraulic gradient) and hydrochemical parameters (TDS, $\mathrm{rNa} / \mathrm{rCl}$, and $\mathrm{rCl}-$ $\mathrm{Na} / \mathrm{rMg}$ ), the region can be divided into five main geochemical areas: (1) recharge area, (2) strong alternating area,

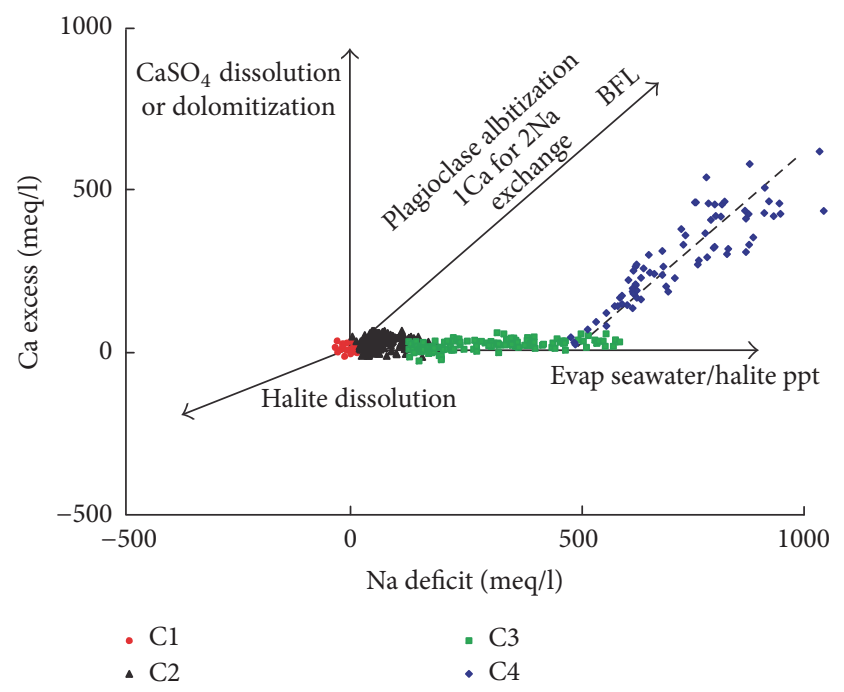

Figure 10: The diagram of Ca excess-Na deficit from different types of formation water in buried hill of Jizhong Depression.

(3) weak alternating area, (4) hydrodynamic blocking area, and (5) discharge area (Figure 11). More detailed description about the boundary of the five areas can be seen in Table 3 . Table 3 also shows the main geochemical areas and geological and hydrogeological contexts with their respective groundwater clusters as well as the main geochemical processes inferred responsible for the hydrogeochemical evolution of groundwater.

5.2.1. Recharge Area. The recharge area, dominated by samples of C1, is in the west of Taihangshan uplift (Figure 11), with a high strong hydraulic gradient, and consists of dolostone. The main anion of $\mathrm{Cl}$ is $\mathrm{HCO}_{3}{ }^{-}$and the main cation is $\mathrm{Na}^{+}$, hydrochemical type of Shu kraft classification is mainly $\mathrm{HCO}_{3}-\mathrm{Na}$, and a small number are $\mathrm{HCO}_{3}-\mathrm{Na} \cdot \mathrm{Mg} \cdot \mathrm{Ca}$. The type of Surin classification is $\mathrm{NaHCO}_{3}$. The ionic ratio ranges between 3.0 and 5.0 for $\mathrm{rNa} / \mathrm{rCl}$ and between -70 and -50 for $\mathrm{r}(\mathrm{Cl}-\mathrm{Na}) / \mathrm{rMg}$. Because the rapid flow and strong influence of atmospheric water, the recharge area with the type of $\mathrm{HCO}_{3}$ $\mathrm{Na}$ and $\mathrm{HCO}_{3}-\mathrm{Na} \cdot \mathrm{Mg} \cdot \mathrm{Ca}$ formation water is characterized by the lowest total dissolved solids $(<1 \mathrm{~g} / \mathrm{l})$ and $\mathrm{r}(\mathrm{Cl}-\mathrm{Na}) / \mathrm{rMg}$ $(<-40)$, highest $\mathrm{rNa} / \mathrm{rCl}(>3)$, suggesting that it is in open hydrogeochemical environment. With its high $\mathrm{HCO}_{3}{ }^{-}, \mathrm{Na}^{+}$, $\mathrm{Mg}^{2+}$, and $\mathrm{Ca}^{2+}$ concentrations, $\mathrm{Cl}$ is clearly recharge formation water. This formation water composition in recharge area results from atmospheric water and dissolution of dolomite.

5.2.2. Strong Alternating Area. The strong alternating area, characterized mainly by $\mathrm{C} 2$ and some $\mathrm{C} 1$, is next to the recharge area (Figure 11), with a relatively high hydraulic gradient, and consists of dolostone. The main anions of $\mathrm{C} 2$ are $\mathrm{Cl}^{-}$and $\mathrm{HCO}_{3}{ }^{-}$and the main cation is $\mathrm{Na}^{+}$, and hydrochemical type of Shu kraft classification is $\mathrm{Cl} \cdot \mathrm{HCO}_{3}$ $\mathrm{Na}$. The type of Surin classification is also $\mathrm{NaHCO}_{3} \cdot \mathrm{rNa} / \mathrm{rCl}$ values mainly vary between 1.1 and 2.8 , and $\mathrm{r}(\mathrm{Cl}-\mathrm{Na}) / \mathrm{rMg}$ values vary between -55 and -10 . The strong alternating area had $\mathrm{Cl} \cdot \mathrm{HCO}_{3}-\mathrm{Na}$ and $\mathrm{HCO}_{3}-\mathrm{Na}$ formation water type, 
TABLE 3: Main geochemical areas and geological and hydrogeological contexts related to groundwater clusters.

\begin{tabular}{|c|c|c|c|c|c|}
\hline $\begin{array}{l}\text { Properties of the } \\
\text { geochemical areas }\end{array}$ & Water supply area & $\begin{array}{l}\text { Strong } \\
\text { alternating area }\end{array}$ & $\begin{array}{l}\text { Weak } \\
\text { alternating area }\end{array}$ & $\begin{array}{l}\text { Hydrodynamic } \\
\text { blocking area }\end{array}$ & Discharge area \\
\hline $\operatorname{TDS}(\mathrm{g} / \mathrm{l})$ & $<1$ & $0.5 \sim 4$ & $4 \sim 15$ & $5 \sim 40$ & $5 \sim 40$ \\
\hline $\mathrm{rNa} / \mathrm{rCl}$ & $>3$ & $1.4 \sim 2.0$ & $1.2 \sim 1.4$ & $0.9 \sim 1.2$ & $0.6 \sim 1.1$ \\
\hline $\mathrm{rCl}-\mathrm{Na} / \mathrm{rMg}$ & $<-40$ & $-50 \sim-20$ & $-15 \sim-5.0$ & $-9 \sim 5$ & $-5 \sim 15$ \\
\hline $\begin{array}{l}\text { Relative hydraulic } \\
\text { gradient }\end{array}$ & Strong & $\begin{array}{l}\text { Strong to } \\
\text { moderate }\end{array}$ & Moderate & $\begin{array}{l}\text { Moderate to } \\
\text { small }\end{array}$ & Small \\
\hline $\begin{array}{l}\text { Hydrogeochemical } \\
\text { environment }\end{array}$ & Open & Semiopen-open & $\begin{array}{l}\text { Semiopen- } \\
\text { semiclosed }\end{array}$ & $\begin{array}{l}\text { semiclosed- } \\
\text { closed }\end{array}$ & $\begin{array}{l}\text { semiclosed- } \\
\text { closed }\end{array}$ \\
\hline $\begin{array}{l}\text { Main groundwater } \\
\text { clusters }\end{array}$ & $\mathrm{C} 1$ & $\mathrm{C} 1, \mathrm{C} 2$ & $\mathrm{C} 2, \mathrm{C} 3$ & $\mathrm{C} 3, \mathrm{C} 4$ & $\mathrm{C} 3, \mathrm{C} 4$ \\
\hline $\begin{array}{l}\text { Main geochemical } \\
\text { processes }\end{array}$ & $\begin{array}{l}\text { (1) Atmospheric } \\
\text { water } \\
\text { (2) Dissolution of } \\
\text { carbonates }\end{array}$ & $\begin{array}{l}\text { (1) Atmospheric } \\
\text { water } \\
\text { (2) Evaporation } \\
\text { concentration } \\
\text { (3) Dissolution } \\
\text { of carbonates }\end{array}$ & $\begin{array}{l}\text { (1) Evaporation } \\
\text { concentration } \\
\text { (2) Atmospheric } \\
\text { water }\end{array}$ & $\begin{array}{l}\text { (1) Evaporation } \\
\text { concentration } \\
\text { (2) Plagioclase } \\
\text { albitization } \\
\text { effect }\end{array}$ & $\begin{array}{l}\text { (1) Evaporation } \\
\text { concentration } \\
\text { (2) Plagioclase } \\
\text { albitization } \\
\text { effect }\end{array}$ \\
\hline $\begin{array}{l}\text { Proven oil reserves } \\
\left(\times 10^{4} \mathrm{t}\right)\end{array}$ & 0 & 0 & 1696 & 42158 & 8038 \\
\hline
\end{tabular}

which is characterized by the lower total dissolved solids $(0.5 \sim 4 \mathrm{~g} / \mathrm{l})$ and $\mathrm{r}(\mathrm{Cl}-\mathrm{Na}) / \mathrm{rMg}(-50 \sim-20)$, higher $\mathrm{rNa} / \mathrm{rCl}$ (1.4 2.0), suggesting that it is in open-semiopen hydrogeochemical environment. With its high $\mathrm{HCO}_{3}{ }^{-}, \mathrm{Cl}^{-}$, and $\mathrm{Na}^{+}$ concentrations, the formation water composition in strong alternating area mainly results from atmospheric water and partly from evaporation concentration.

5.2.3. Weak Alternating Area. The weak alternating area, characterized mainly by $\mathrm{C} 2$ and some C3, is in lower uplift (Figure 11), with a strong to moderate gradient, and consists of dolostone and limestone. Because the movement of formation water in weak alternating area is still relatively active, the weak alternating area had $\mathrm{Cl} \cdot \mathrm{HCO}_{3}-\mathrm{Na}$ and $\mathrm{Cl}-$ $\mathrm{Na}$ formation water type, which is characterized by the lower total dissolved solids $(4 \sim 15 \mathrm{~g} / \mathrm{l})$ and $\mathrm{r}(\mathrm{Cl}-\mathrm{Na}) / \mathrm{rMg}$ $(-15 \sim-5)$, higher $\mathrm{rNa} / \mathrm{rCl}(1.2 \sim 1.4)$, suggesting that it is in semiopen-semiclosed hydrogeochemical environment. With its high $\mathrm{Cl}^{-}, \mathrm{Na}^{+}$, and $\mathrm{HCO}_{3}{ }^{-}$concentrations, the formation water composition in weak alternating area mainly results from evaporation concentration and partly from atmospheric water.

5.2.4. Hydrodynamic Blocking Area. The hydrodynamic blocking area, dominated by samples of $\mathrm{C} 3$ and $\mathrm{C} 4$, is in the middle of Jizhong Depression (Figure 11), with a low hydraulic gradient, and consists of dolostone and limestone. The main anion of $\mathrm{C} 4$ is $\mathrm{Cl}^{-}$and the main cations are $\mathrm{Na}^{+}$ and $\mathrm{Ca}^{2+}$, and hydrochemical type of Shu kraft classification is $\mathrm{Cl}-\mathrm{Na} \cdot \mathrm{Ca}$. The type of Surin classification is $\mathrm{CaCl}_{2}$. The $\mathrm{rNa} / \mathrm{rCl}$ and $\mathrm{r}(\mathrm{Cl}-\mathrm{Na}) / \mathrm{rMg}$ of $\mathrm{C} 4$ display relatively narrow range from 0.3 to 1.0 and from 4 to 18 , respectively. Based on the above dates, the $\mathrm{C} 4$ water is in closed hydrogeochemical environment. Due to being far away from recharge area, the flow of formation water in the hydrodynamic blocking area is slow. Hydrodynamic blocking area had $\mathrm{Cl}-\mathrm{Na}$ and
$\mathrm{Cl}-\mathrm{Na} \cdot \mathrm{Ca}$ formation water type, which is characterized by the higher total dissolved solids $(5 \sim 40 \mathrm{~g} / \mathrm{l})$ and $\mathrm{r}(\mathrm{Cl}-\mathrm{Na}) / \mathrm{rMg}$ $(-8 \sim 5)$, lower $\mathrm{rNa} / \mathrm{rCl}(0.9 \sim 1.2)$, suggesting that it is in semiclosed-closed hydrogeochemical environment. With its high $\mathrm{Cl}^{-}, \mathrm{Na}^{+}$, and $\mathrm{Ca}^{2+}$ concentrations, the formation water composition in hydrodynamic blocking area mainly results from evaporation concentration and plagioclase albitization effect.

5.2.5. Discharge Area. The discharge area, also dominated by samples of C3 and C4, is in the east of Jizhong Depression (Figure 11), with a low hydraulic gradient, and consists of limestone. The discharge area had $\mathrm{Cl}-\mathrm{Na}$ and $\mathrm{Cl}-\mathrm{Na} \cdot \mathrm{Ca}$ formation water type, which are characterized by the higher total dissolved solids (5 40 g/l) and $\mathrm{r}(\mathrm{Cl}-\mathrm{Na}) / \mathrm{rMg}(-5 \sim-15)$, lower $\mathrm{rNa} / \mathrm{rCl}(0.6 \sim 1.1)$, suggesting that it is in semiclosed-closed hydrogeochemical environment. With its high $\mathrm{Cl}^{-}, \mathrm{Na}^{+}$, and $\mathrm{Ca}^{2+}$ concentrations, the formation water composition in discharge area mainly results from evaporation concentration and plagioclase albitization effect.

In conclusion, from the recharge area to the discharge area, the type of formation water in buried hill changed from $\mathrm{C} 1$ to $\mathrm{C} 2, \mathrm{C} 3$, and then $\mathrm{C} 4$ (Figure 11). The waterrock interaction becomes increasingly intensive and the total dissolved solid gets higher, resulting in a transition of the water chemical type; for example, $\mathrm{rNa} / \mathrm{rCl}$ and $\mathrm{rSO}_{4} \times$ $100 / \mathrm{rCl}$ get lower while $\mathrm{r}(\mathrm{Cl}-\mathrm{Na}) / \mathrm{rMg}$ gets higher. Due to the influence of atmospheric water and dissolution of dolomite, the recharge area is characterized by $\mathrm{Cl}$ formation water $\left(\mathrm{HCO}_{3}-\mathrm{Na}\right.$ and $\left.\mathrm{HCO}_{3}-\mathrm{Na} \cdot \mathrm{Mg} \cdot \mathrm{Ca}\right)$. From recharge area to strong alternating area, the influence of atmospheric water gets weak and evaporation concentration effect gets strong; formation water belonging to $\mathrm{Cl}\left(\mathrm{HCO}_{3}-\mathrm{Na}\right.$ and $\mathrm{HCO}_{3}$ $\mathrm{Na} \cdot \mathrm{Mg} \cdot \mathrm{Ca}$ ) evolves along its flow path into formation water of $\mathrm{C} 2\left(\mathrm{Cl} \cdot \mathrm{HCO}_{3}-\mathrm{Na}\right)$. From strong alternating area to weak 


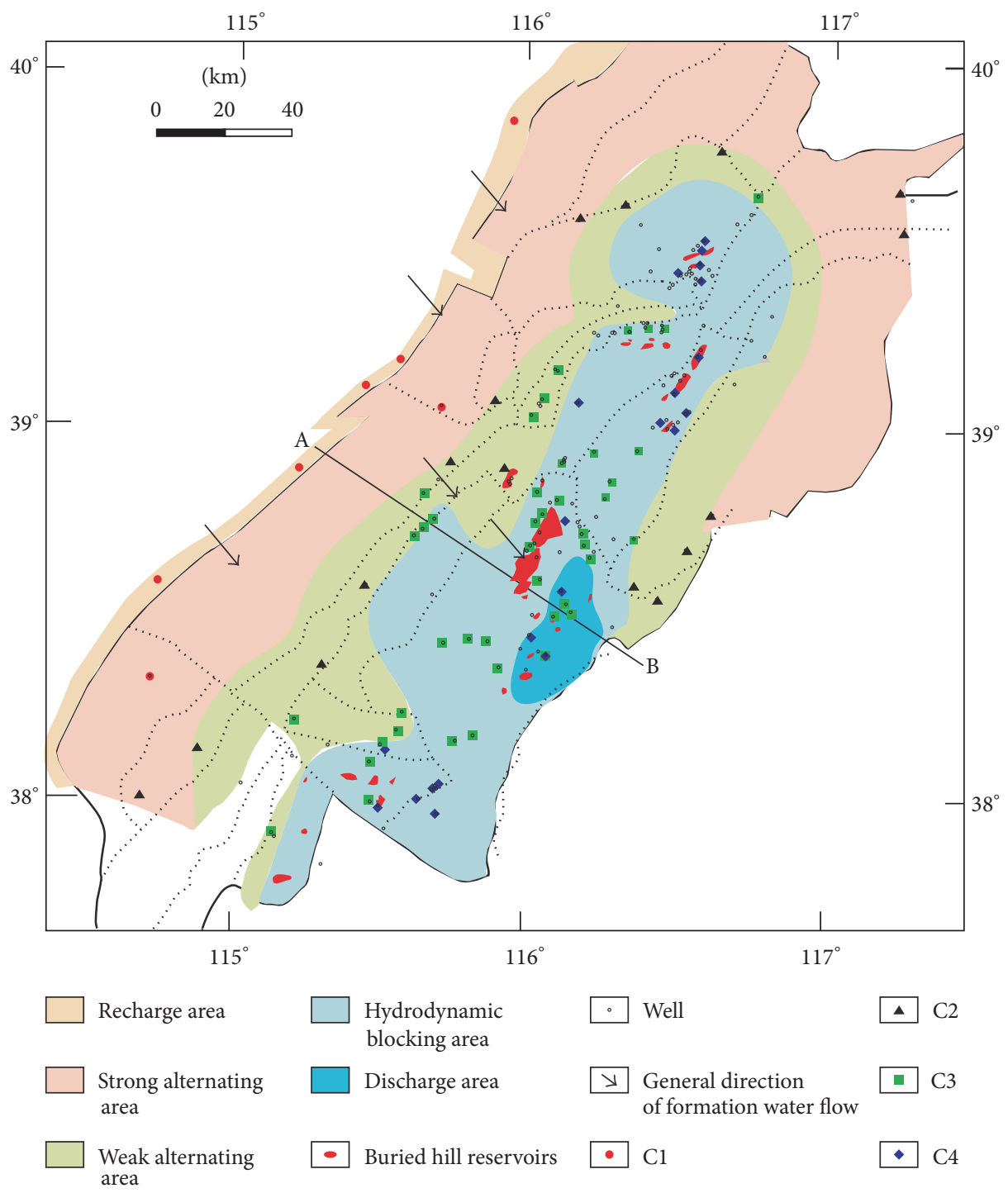

FIgURE 11: The analysis of hydrodynamic conditions in buried hill, Jizhong Depression.

alternating area, the influence of atmospheric water gets weaker and evaporation concentration effect gets stronger; formation water belonging to $\mathrm{C} 2\left(\mathrm{Cl} \cdot \mathrm{HCO}_{3}-\mathrm{Na}\right)$ evolves along its flow path into formation water of $\mathrm{C} 3(\mathrm{Cl}-\mathrm{Na})$. From weak alternating area to hydrodynamic blocking area and discharge area, formation water belonging to $\mathrm{C} 3(\mathrm{Cl}-$ $\mathrm{Na}$ ) evolves along its flow path by $\mathrm{Ca}^{2+}-\mathrm{Na}^{+}$ion exchange (plagioclase albitization effect) into formation water of $\mathrm{C} 4$ (Cl-Na.Ca) (Figure 11).

\subsection{The Implication of Origin and Evolution of Formation} Water in Buried Hill for Hydrocarbon Distribution. More than 23 buried hill oil fields and $5.19 \times 10^{8} \mathrm{t}$ proven oil in place in these fields have been discovered by the year 2015. Based on the analysis of the type of formation water and proven oil reserves in these 23 buried hill oil fields, the influence of the types of formation water in buried hill on the distribution of buried hill oil reserves was researched. The results showed that more than $87 \%\left(4.51 \times 10^{8} \mathrm{t}\right)$ of proven oil reserves are related to $\mathrm{Cl}-\mathrm{Na}(\mathrm{C} 3)$ type water, $10 \%\left(0.51 \times 10^{8} \mathrm{t}\right)$ of proven oil reserves are related to $\mathrm{Cl}-\mathrm{Na} \cdot \mathrm{Ca}(\mathrm{C} 4)$ type water, $3 \%\left(0.17 \times 10^{8} \mathrm{t}\right)$ of proven oil reserves are related to $\mathrm{Cl} \cdot \mathrm{HCO}_{3}$ $\mathrm{Na}$ (C2) type water, and no oil is found in $\mathrm{HCO}_{3}-\mathrm{Na}(\mathrm{C} 1)$ type water (Figure 12). Therefore, the buried hill reservoirs in Jizhong Depression are mainly related to the C3 ( Cl-Na) and $\mathrm{C} 4(\mathrm{Cl}-\mathrm{Na} \cdot \mathrm{Ca})$ types water which are in semiclosedclosed hydrogeochemical environment. No or less buried hill reservoir was found in $\mathrm{HCO}_{3}-\mathrm{Na}(\mathrm{Cl})$ and $\mathrm{Cl} \cdot \mathrm{HCO}_{3}-\mathrm{Na}(\mathrm{C} 2)$ types water which are in semiopen-open hydrogeochemical environment.

The article also studied the influence of hydrodynamic environment on the distribution of buried hill oil reserves. The results showed that more than $81 \%\left(4.22 \times 10^{8} \mathrm{t}\right)$ of proven oil reserves are distributed in hydrodynamic blocking area, $15 \%\left(0.81 \times 10^{8} \mathrm{t}\right)$ of proven oil reserves are distributed in discharge area, $4 \%\left(0.17 \times 10^{8} \mathrm{t}\right)$ of proven oil reserves are distributed in weak alternating area, and no oil was found in recharge area and strong alternating area (Figure 13). Because 


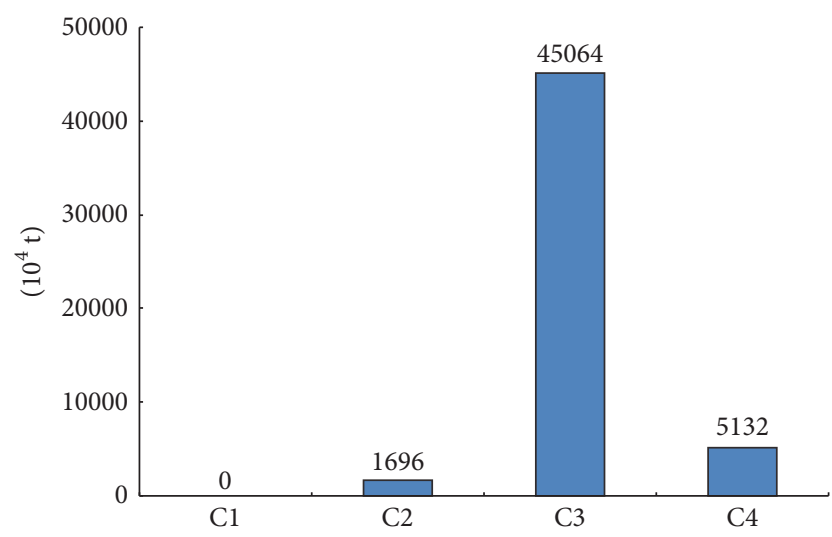

Figure 12: Proven oil reserves in different types of formation water in buried hill, Jizhong Depression.

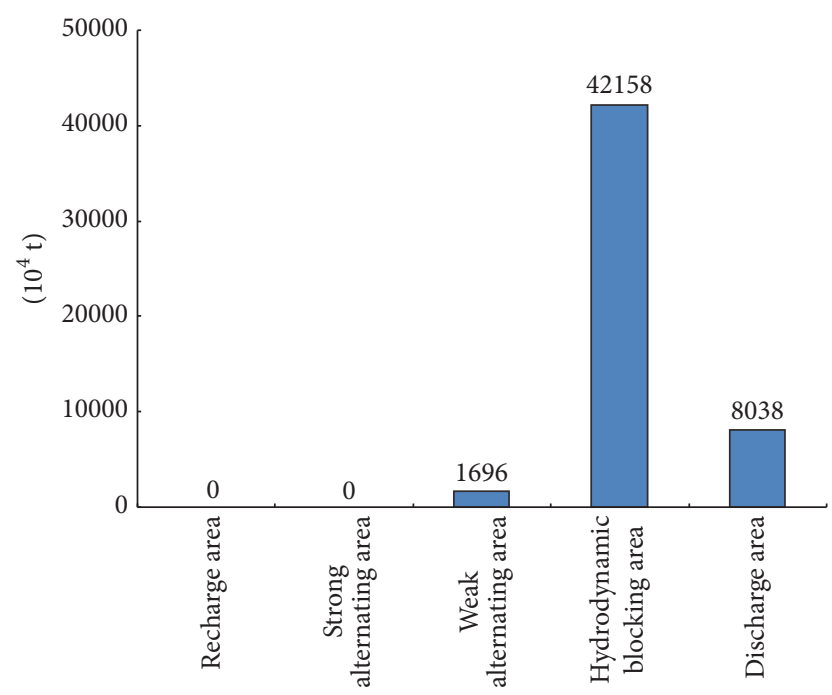

FIGURE 13: Proven oil reserves in different hydrodynamic systems of buried hill, Jizhong Depression.

the rapid flow and strong influence of atmospheric water, the preservation condition of oil and gas is poor and no oil and gas were found in recharge area and strong alternating area. The movement of formation water in weak alternating area is still relatively active and the oil and gas can only be preserved in relatively weak hydrodynamic areas. So less oil and gas were found in weak alternating area. Due to being far away from recharge area, the flow of formation water in the hydrodynamic blocking area and discharge area is slow and they are favorable regions to preserve oil and gas. Therefore, more than $95 \%$ of buried hill oil in Jizhong Depression is distributed in hydrodynamic blocking area and discharge area.

The above study shows that the buried hill reserves of Jizhong Depression are mainly distributed in hydrodynamic blocking area and discharge area whose formation water types are $\mathrm{Cl}-\mathrm{Na}$ and $\mathrm{Cl}-\mathrm{Na} \cdot \mathrm{Ca}$, so the two regions can be the favorable areas for petroleum migration.

\section{Conclusion}

(1) The hierarchical cluster analysis (HCA) classified 459 formation water samples in buried hill of Jizhong Depression into four geochemically distinct clusters (C1-C4). $\mathrm{Cl}$ is mostly located in recharge area of west Taihangshan uplift, the main anion is $\mathrm{HCO}_{3}{ }^{-}$and the main cation is $\mathrm{Na}^{+}$, and hydrochemical type is $\mathrm{HCO}_{3}{ }^{-}$ $\mathrm{Na}$, which is in open hydrogeochemical environment. C2 is mainly in high uplift of buried hill, the main anions are $\mathrm{Cl}^{-}$and $\mathrm{HCO}_{3}^{-}$and the main cation is $\mathrm{Na}^{+}$, and hydrochemical type is $\mathrm{Cl} \cdot \mathrm{HCO}_{3}-\mathrm{Na}$, which is in semiopen hydrogeochemical environment. C3 is mainly in the slope between the buried hill and sag, the main anion is $\mathrm{Cl}^{-}$and the main cation is $\mathrm{Na}^{+}$, and hydrochemical type is $\mathrm{Cl}-\mathrm{Na}$, which is in semiclosed hydrogeochemical environment. C4 is mainly in the buried hill of sag, the main anion is $\mathrm{Cl}^{-}$and the main cations are $\mathrm{Na}^{+}$and $\mathrm{Ca}^{2+}$, and hydrochemical type is $\mathrm{Cl}-\mathrm{Na} \cdot \mathrm{Ca}$, which is in closed hydrogeochemical environment.

(2) With the burial depth increment, the type of formation water in buried hill changed from $\mathrm{C} 1$ to $\mathrm{C} 2$, $\mathrm{C} 3$, and then $\mathrm{C} 4$; the water-rock interactions become increasingly intensive and the mineralization degree gets higher, resulting in a transition of the water chemical type, for example, $\mathrm{rNa} / \mathrm{rCl}$ gets lower while total dissolved solids and $\mathrm{r}(\mathrm{Cl}-\mathrm{Na}) / \mathrm{rMg}$ get higher.

(3) Three components of the principal components analysis (PCA) explain $86.87 \%$ of the variance in the dataset. $\mathrm{PCl}$, characterized by highly positive loadings in $\mathrm{Na}^{+}$and $\mathrm{Cl}^{-}$, is related to evaporation concentration. PC2 is defined by highly positive loadings in $\mathrm{HCO}_{3}{ }^{-}$and is related to influence of atmospheric water. With high positive loadings in $\mathrm{Ca}^{2+}$ and high negative loadings in $\mathrm{Na}^{+}$and $\mathrm{SO}_{4}{ }^{2-}, \mathrm{PC} 3$ suggests the influences of plagioclase albitization.

(4) $\mathrm{Cl}$ with $\mathrm{HCO}_{3}-\mathrm{Na}$ formation water, mainly affected by $\mathrm{PC} 2$, is mainly from atmospheric infiltration water. $\mathrm{C} 2$ with $\mathrm{Cl} \cdot \mathrm{HCO}_{3}-\mathrm{Na}$ formation water is affected by $\mathrm{PC} 1$ and PC2, suggesting that it is derived from atmospheric water and evaporation concentration effect. C3 with $\mathrm{Cl}-\mathrm{Na}$ formation water is affected by PCl, suggesting that evaporation concentration effect plays an important part role during the formation of the $\mathrm{C} 3$. $\mathrm{C} 4$ with $\mathrm{Cl}-\mathrm{Na} \cdot \mathrm{Ca}$ formation water, mainly affected by PC2 and PC3, is mainly from the deposition water and evaporation concentration and plagioclase albitization effect play important roles during the formation of $\mathrm{C} 4$.

(5) The combination of HCA and PCA within the geological and hydrogeological contexts allowed the division of the study area into five dynamic areas (recharge area, strong alternating area, weak alternating area, hydrodynamic blocking area, and discharge area). From the recharge area to discharge area, the influence of atmospheric water gets weak and the water-rock interactions such as evaporation 
concentration and plagioclase albitization become increasingly intensive; therefore the recharge area is dominated by samples of $\mathrm{C} 1$, strong alternating area is dominated by samples of $\mathrm{C} 1$ and $\mathrm{C} 2$, weak alternating area is dominated by samples of $\mathrm{C} 2$ and $\mathrm{C} 3$, and hydrodynamic blocking area and discharge area are dominated by samples of $\mathrm{C} 3$ and $\mathrm{C} 4$.

(6) Buried hill reservoir in Jizhong Depression is mainly distributed in hydrodynamic blocking area and discharge area; therefore the two regions can be the favorable areas for petroleum migration and the above statistical analyses' methodology can be used in the other study areas which have similar geological and hydrogeological background to the study area.

\section{Conflicts of Interest}

The authors declare that they have no conflicts of interest.

\section{Acknowledgments}

This study was financially supported by the National Science and Technology Special Grant (no. 2016ZX05006-001). Thanks are also given to Huabei Oilfield Company of Sinopec, which provided all the related data of Jizhong Depression.

\section{References}

[1] H. G. Machel, "Bacterial and thermochemical sulfate reduction in diagenetic settings - old and new insights," Sedimentary Geology, vol. 140, no. 1-2, pp. 143-175, 2001.

[2] K. Michael and S. Bachu, "Origin, chemistry and flow of formation waters in the Mississippian-Jurassic sedimentary succession in the west-central part of the Alberta Basin, Canada," Marine and Petroleum Geology, vol. 19, no. 3, pp. 289306, 2002.

[3] X. Xie, Z. Fan, X. Liu, and Y. Lu, "Geochemistry of formation water and its implication on overpressured fluid flow in the Dongying Depression of the Bohaiwan Basin, China," Journal of Geochemical Exploration, vol. 89, no. 1-3, pp. 432-435, 2006.

[4] Y. Fu and H. Zhan, "On the origin of oil-field water in the Biyang Depression of China," Environmental Geology, vol. 58, no. 6, pp. 1191-1196, 2009.

[5] Y. Wang, H. Xu, C. Wang, and B. Jia, "Characteristics of the salinity and distribution of the Neopaleozoic formation water in Ordos Basin," Shiyou Xuebao/Acta Petrolei Sinica, vol. 31, no. 5, pp. 748-761, 2010.

[6] R. Bagheri, A. Nadri, E. Raeisi, H. G. M. Eggenkamp, G. A. Kazemi, and A. Montaseri, "Hydrochemical and isotopic $(\delta 18 \mathrm{O}$, $\delta 2 \mathrm{H}, 87 \mathrm{Sr} / 86 \mathrm{Sr}, \delta 37 \mathrm{Cl}$ and $\delta 81 \mathrm{Br}$ ) evidence for the origin of saline formation water in a gas reservoir," Chemical Geology, vol. 384, pp. 62-75, 2014.

[7] J. S. Hanor and J. C. Mcintosh, "Diverse origins and timing of formation of basinal brines in the Gulf of Mexico sedimentary basin," Geofluids, vol. 7, no. 2, pp. 227-237, 2007.

[8] Y. K. Kharaka and J. S. Hanor, "Deep Fluids in the Continents: I. Sedimentary Basins," Treatise on Geochemistry, vol. 5-9, pp. $1-48,2003$.
[9] M. Tesmer, P. Möller, S. Wieland, C. Jahnke, H. Voigt, and A. Pekdeger, "Deep reaching fluid flow in the North East German Basin: Origin and processes of groundwater salinisation," Hydrogeology Journal, vol. 15, no. 7, pp. 1291-1306, 2007.

[10] P. Birkle and R. A. Maruri, "Isotopic indications for the origin of formation water at the Activo Samaria-Sitio Grande oil field, Mexico," Journal of Geochemical Exploration, vol. 78-79, pp. 453-458, 2003.

[11] T. K. Lowenstein, L. A. Hardie, M. N. Timofeeff, and R. V. Demicco, "Secular variation in seawater chemistry and the origin of calcium chloride basinal brines," Geology, vol. 31, no. 10, pp. 857-860, 2003.

[12] S. V. Panno, K. C. Hackley, R. A. Locke et al., "Formation waters from Cambrian-age strata, Illinois Basin, USA: constraints on their origin and evolution," Geochimica et Cosmochimica Acta, vol. 122, pp. 184-187, 2013.

[13] I. M. Farnham, K. H. Johannesson, A. K. Singh, V. F. Hodge, and K. J. Stetzenbach, "Factor analytical approaches for evaluating groundwater trace element chemistry data," Analytica Chimica Acta, vol. 490, no. 1-2, pp. 123-138, 2003.

[14] V. Cloutier, R. Lefebvre, R. Therrien, and M. M. Savard, "Multivariate statistical analysis of geochemical data as indicative of the hydrogeochemical evolution of groundwater in a sedimentary rock aquifer system," Journal of Hydrology, vol. 353, no. 3-4, pp. 294-313, 2008.

[15] S. M. Yidana, D. Ophori, and B. Banoeng-Yakubo, "A multivariate statistical analysis of surface water chemistry data-The Ankobra Basin, Ghana," Journal of Environmental Management, vol. 86, no. 1, pp. 80-87, 2008.

[16] P. S. Yang and G. Z. Li, "Development of carbonate reservoirs in the Renqiu Oil Field," Acta Petrolei Sinica, vol. 1, pp. 57-64, 1980.

[17] X. Zhao, Q. Wang, F. Jin et al., "Main controlling factors and exploration practice of subtle buried-hill hydrocarbon reservoir in Jizhong depression," Shiyou Xuebao/Acta Petrolei Sinica, vol. 33, no. 1, pp. 71-79, 2012.

[18] C. H. Gao, M. Zha, X. Z. Zhao, and F. Peng, "Migration systems and hydrocarbon accumulation models of buried hill reservoirs in Jizhong Depression," Lithologic Reservoirs, vol. 2, pp. 26-30, 2015.

[19] X. Zhao, F. Jin, Y. Wang, Y. Guo, J. Liu, and R. Zheng, "Buriedhill reservoir-forming mode of 'old reservoir-old sealing formation' in Changyangdian area of Jizhong Depression," Shiyou Xuebao/Acta Petrolei Sinica, vol. 29, no. 4, pp. 489-493, 2008.

[20] X. Zhao, F. Jin, Q. Wang et al., "Niudong 1 ultra-deep and ultrahigh temperature subtle buried hill field in Bohai Bay Basin: discovery and significance," Shiyou Xuebao/Acta Petrolei Sinica, vol. 32, no. 6, pp. 915-927, 2011.

[21] Q. H. Chen, H. G. Lao, K. Y. Wu, Z. H. Wu, and Y. Q. Cui, "Favorable hydrocabon accumulation conditions for carbonate reservoirs in deepburied hills in the Jizhong Deprssion," Natural Gas Industry, vol. 27, pp. 32-39, 2013.

[22] S. Sun, J. S. Xie, G. R. Li, and C. Y. Qiu, "Hydrogen and oxygen isotopic composition and genesis of the ground water in Jizhong Depression,” Oil Gas Geology, vol. 3, pp. 240-250, 1982.

[23] B. P. Han, "Study on chemistry of oilfield water in buried block hill in Jizhong Depression," Scientia Geologica Sinica, vol. 3, pp. 263-273, 1989.

[24] Y. H. Qu, Z. C. Sun, X. J. Feng, and Z. M. Chen, "Middle-upper proterozoic buried hill groundwater geohydrologic character and significance for exploration in northern Jizhong depression 
basin," Journal of Daqing Petroleum Institute, vol. 23, pp. 8-11, 1999.

[25] C. J. Daughney and R. R. Reeves, "Definition of hydrochemical facies in the New Zealand National Groundwater Monitoring Programme," Journal of Hydrology (New Zealand), vol. 44, no. 2, pp. 105-130, 2005.

[26] B. O'Shea and J. Jankowski, "Detecting subtle hydrochemical anomalies with multivariate statistics: An example from 'homogeneous' groundwaters in the Great Artesian Basin, Australia," Hydrological Processes, vol. 20, no. 20, pp. 4317-4333, 2006.

[27] S. X. Li, M. J. Chu, T. F. Wang, and W. X. Zhang, "Features of formation water and implications for hydrocarbon accumulation in Chang 6 pay zone, Jiyuan area, Ordos Basin," China Petroleum Exploration, vol. 22, pp. 43-52, 2017.

[28] J. Wang, Z. Lou, R. Zhu et al., "Hydrochemistry of Paleogene formation water and its relationship with hydrocarbon migration and accumulation in Wenliu region in Dongpu sag, Bohai Bay Basin," Oil and Gas Geology, vol. 35, no. 4, pp. 449-455, 2014.

[29] M. L. Davisson, T. S. Presser, and R. E. Criss, "Geochemistry of tectonically expelled fluids from the northern Coast ranges, Rumsey Hills, California, USA," Geochimica et Cosmochimica Acta, vol. 58, no. 7, pp. 1687-1699, 1994.

[30] K. S. Lu, Y. J. Li, and Y. K. Wu, "Tectonic evolution of buried hill in JiZhong Depression and petroleum geological significance," Journal of oil and gas technology, vol. 33, pp. 35-42, 2011.

[31] D. Dong, L. Li, J. Liu, and J. Li, "Cenozoic tectonic evolution in the north-central Jizhong Depression," Oil and Gas Geology, vol. 34, no. 6, pp. 771-780, 2013.

[32] H. G. Lao, K. Y. Wu, and Q. H. Chen, "Geology character and evolution of the accommodation zone in the JiZhong Depression," Journal of geomechanics, vol. 16, pp. 294-309, 2010.

[33] J. H. Du, H. W. Zou, B. S. Fei, H. Y. Lei, F. Z. Zhang, and Y. M. Zhang, BurieD Hill Composite Hydrocarbon Accumulation Zone of Jizhong Depression, Science Press, 2002.

[34] R. K. Steinhorst and R. E. Williams, "Discrimination of groundwater sources using cluster analysis, MANOVA, Canonical Analysis and Discriminant Analysis," Water Resources Research, vol. 21, no. 8, pp. 1149-1156, 1985.

[35] C. Güler, G. D. Thyne, J. E. McCray, and A. K. Turner, "Evaluation of graphical and multivariate statistical methods for classification of water chemistry data," Hydrogeology Journal, vol. 10, no. 4, pp. 455-474, 2002.

[36] E. M. Adar, E. Rosenthal, A. S. Issar, and O. Batelaan, "Quantitative assessment of the flow pattern in the southern Arava Valley (Israel) by environmental tracers and a mixing cell model," Journal of Hydrology, vol. 136, no. 1-4, pp. 333-352, 1992.

[37] P. P. Schot and J. van der Wal, "Human impact on regional groundwater composition through intervention in natural flow patterns and changes in land use," Journal of Hydrology, vol. 134, no. 1-4, pp. 297-313, 1992.

[38] J. C. Davis, Statistics and Data Analysis in Geology, John Wiley \& Sons Inc, New York, NY, USA, 1986.

[39] A. Melloul and M. Collin, “The 'principal components' statistical method as a complementary approach to geochemical methods in water quality factor identification; application to the Coastal Plain aquifer of Israel," Journal of Hydrology, vol. 140, no. 1-4, pp. 49-73, 1992.

[40] T. C. Winter, S. E. Mallory, T. R. Allen, and D. O. Rosenberry, "The use of principal component analysis for interpreting ground water hydrographs," Groundwater, vol. 38, no. 2, pp. 234-246, 2000.
[41] G. Thyne, C. Güler, and E. Poeter, "Sequential analysis of hydrochemical data for watershed characterization," Groundwater, vol. 42, no. 5, pp. 711-723, 2004.

[42] StatSoft Inc STATISTICA (Data Analysis Software System, Version 6, 2004.

[43] C. J. Daughney, M. Raiber, M. Moreau-Fournier, U. Morgenstern, and R. van der Raaij, "Use of hierarchical cluster analysis to assess the representativeness of a baseline groundwater quality monitoring network: comparison of New Zealand's national and regional groundwater monitoring programs," Hydrogeology Journal, vol. 20, no. 1, pp. 185-200, 2012.

[44] W. J. Xiao, J. R. Lu, Q. X. Liu et al., "Analysis of geochemical characteristics and formation age of gethermal fluid deposited in Beiyuan Jiayuan to Beijing Olympic Park Area," Earth Science Frontiers, vol. 16, pp. 384-395, 2009.

[45] L. Luo, Z. Pang, and F. Yang, "Genesis analysis of sulfate thermal mineral water in carbonate aquifers at Jianhu Uplift, Subei Basin," Earth Science Frontiers, vol. 22, no. 2, pp. 263-270, 2015.

[46] G. Lin, J. A. Nunn, and D. Deming, "Thermal buffering of sedimentary basins by basement rocks: Implications arising from numerical simulations," Petroleum Geoscience, vol. 6, no. 4, pp. 299-307, 2000.

[47] I. M. Farnham, K. J. Stetzenbach, A. K. Singh, and K. H. Johannesson, "Deciphering groundwater flow systems in Oasis Valley, Nevada, using trace element chemistry, multivariate statistics, and geographical information system," Mathematical Geology, vol. 32, no. 8, pp. 943-968, 2000.

[48] K. J. Stetzenbach, V. F. Hodge, C. Guo, I. M. Farnham, and K. H. Johannesson, "Geochemical and statistical evidence of deep carbonate groundwater within overlying volcanic rock aquifers/aquitards of southern Nevada, USA," Journal of Hydrology, vol. 243, no. 3-4, pp. 254-271, 2001.

[49] M. L. Davisson and R. E. Criss, "Na-Ca-Cl relations in basinal fluids," Geochimica et Cosmochimica Acta, vol. 60, no. 15, pp. 2743-2752, 1996. 

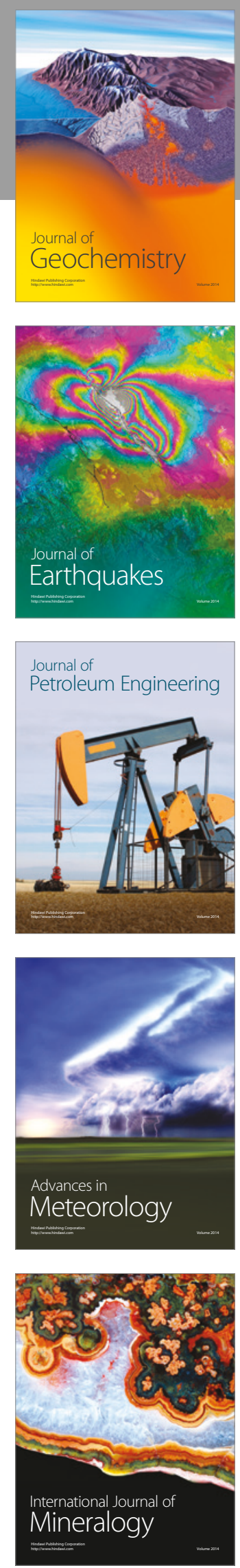
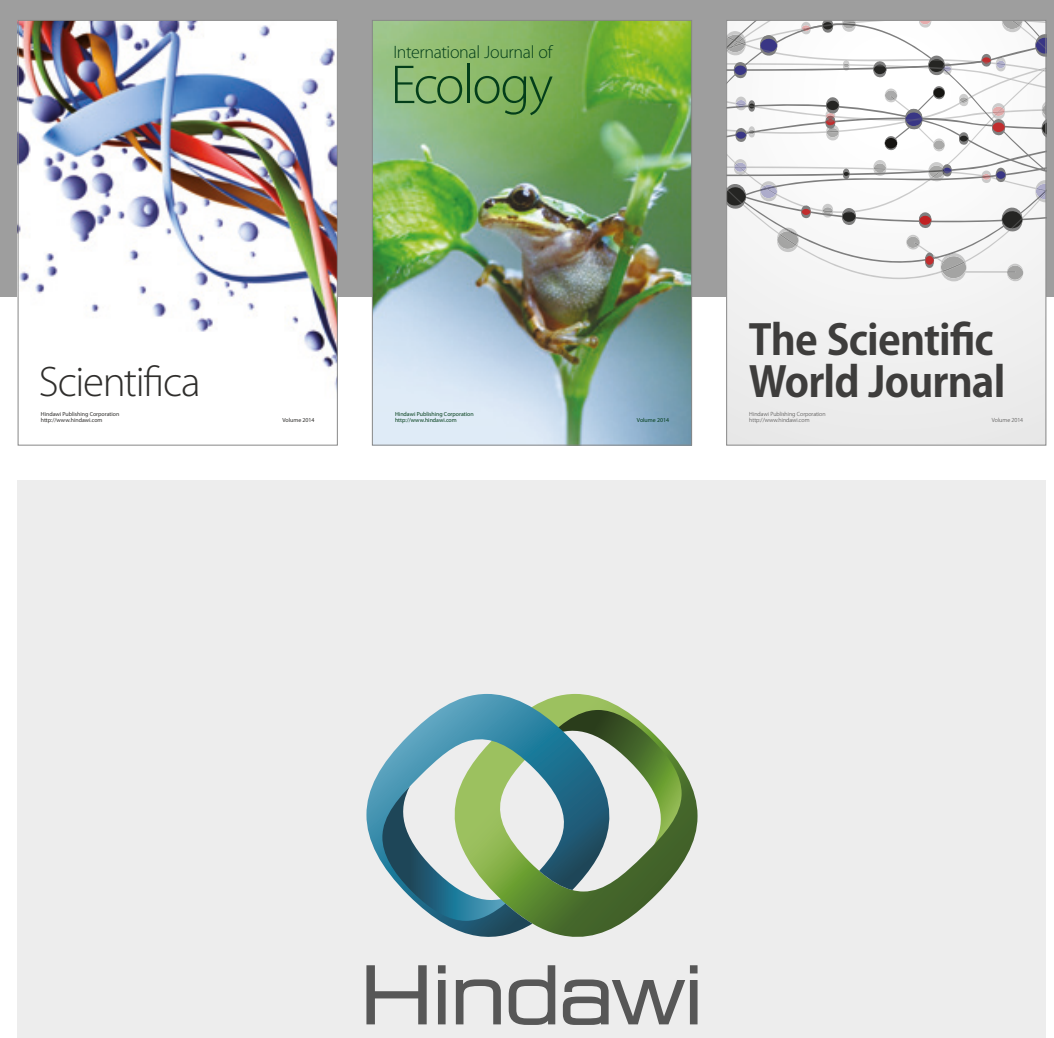

Submit your manuscripts at

https://www.hindawi.com
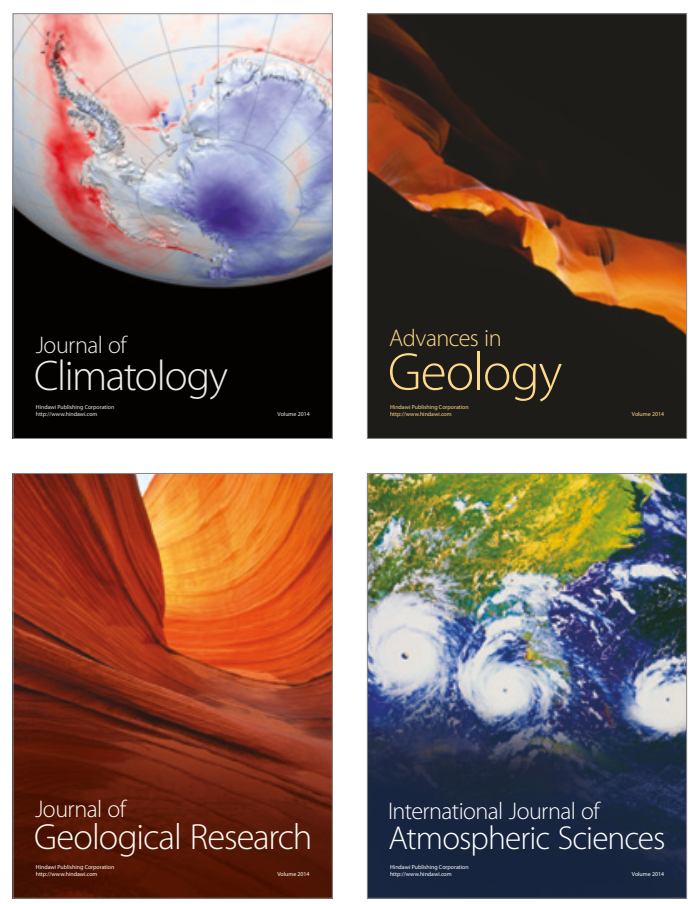

The Scientific

World Journal
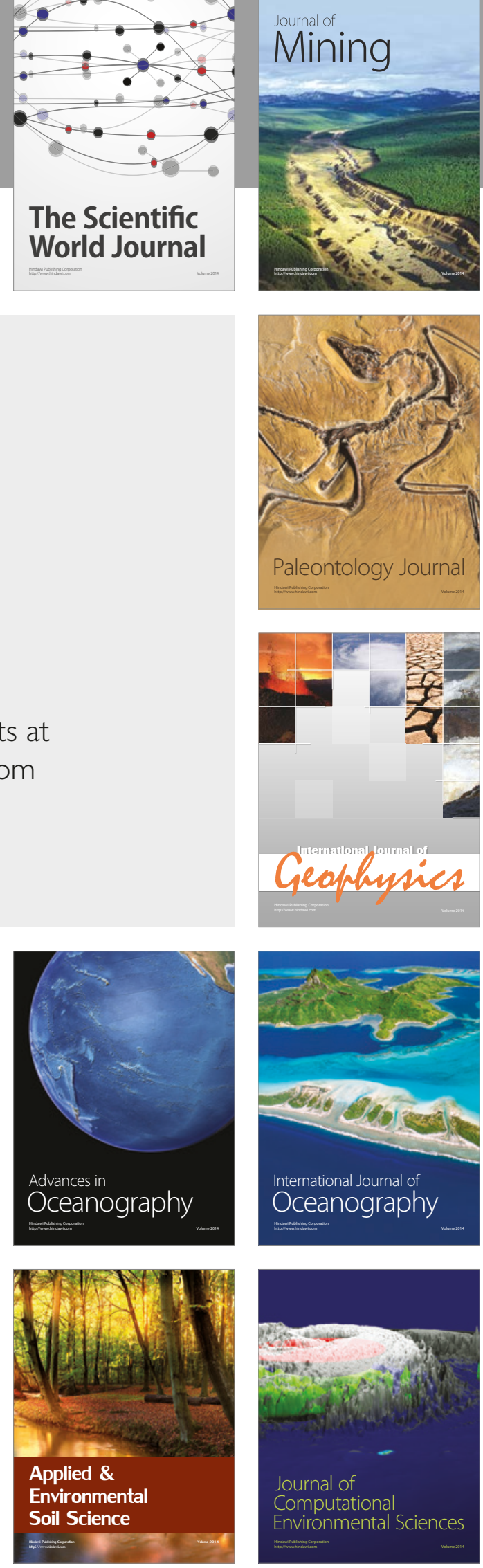